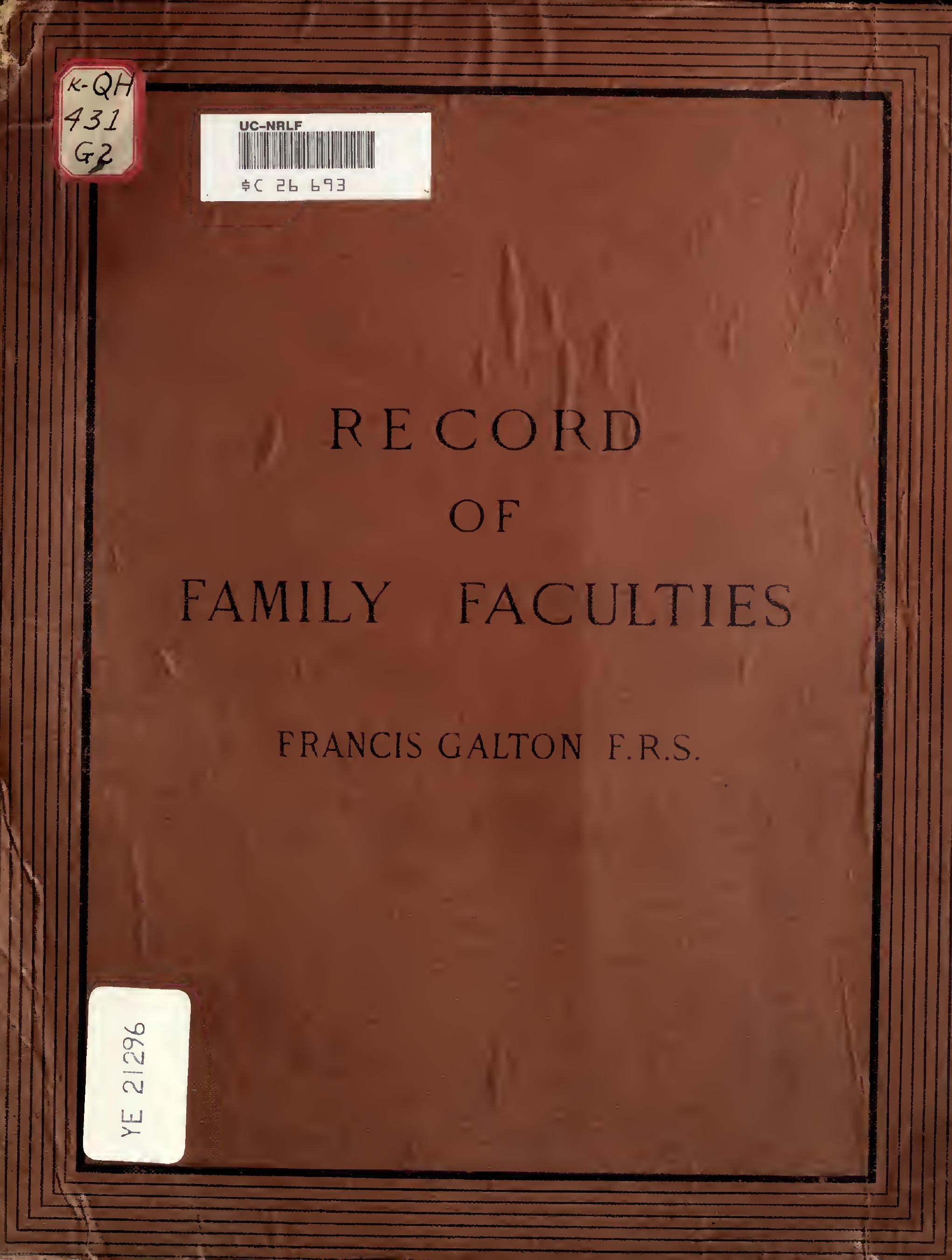




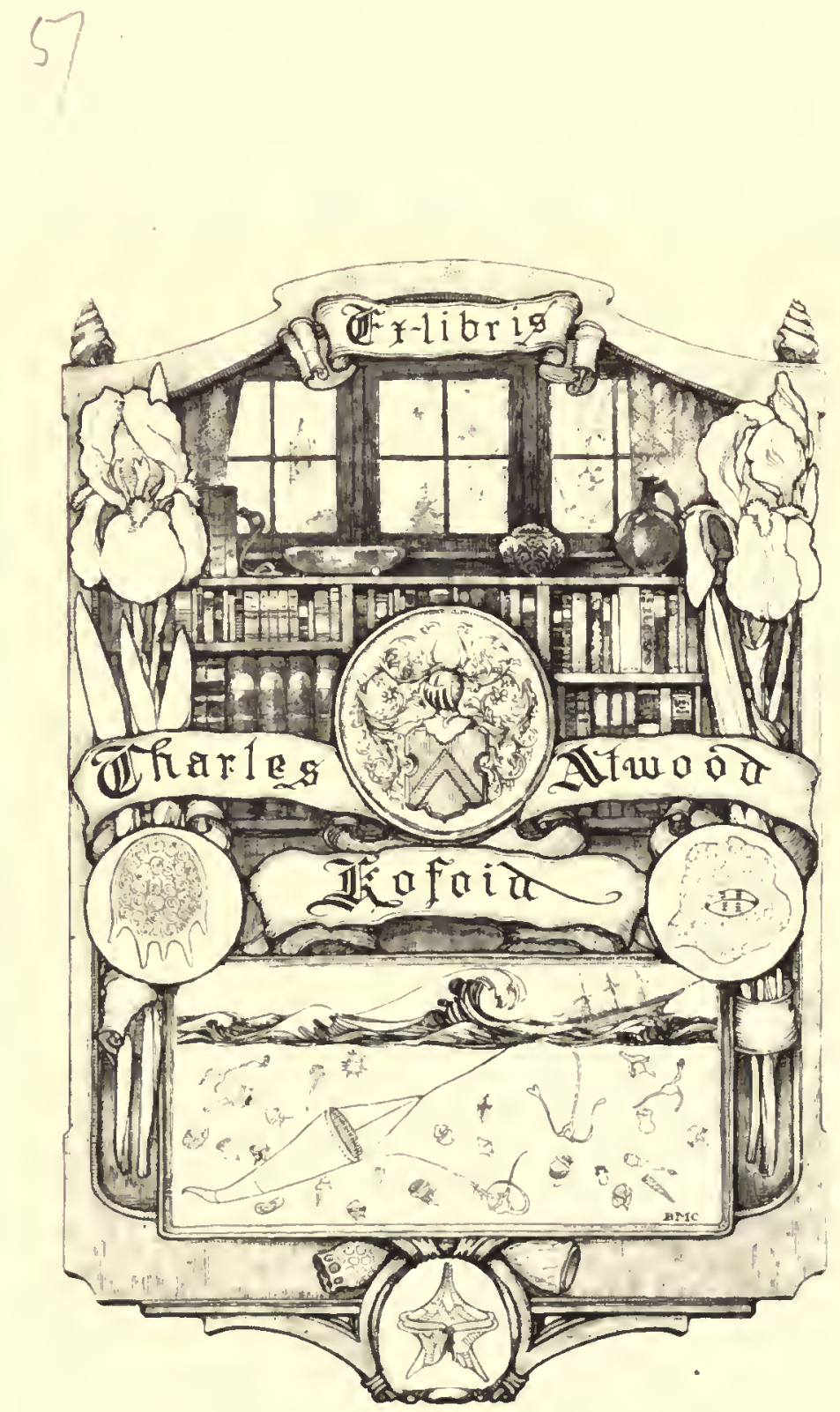




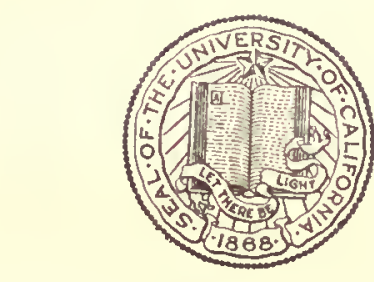

\section{THE LIBRARY OF}

\section{THE UNIVERSITY OF CALIFORNIA}

PRESENTED BY

PROF. CHARLES A. KOFOID AND

MRS. PRUDENCE W. KOFOID 
• 


\section{RECORD OF FAMILY FACULTIES.}


s. 
RECORD OF FAMILY FACULTIES.

CONSISTING OF TABULAR FORMS

AND DIRECTIONS FOR ENTERING DATA,

พITH

AN EXPLANATORY PREFACE

BY

FRANCIS GALTON, F.R.S.,

AUTHOR OF

"hrRedtary genius," "inguiries into human faculty and its develulient," etc.

Tollooll :

MACMILLAN AND CO.

1884. 
LoNnox

f. ClAY, soss, AXD TAYLol, HRINTHE, LREAT) STHELT HILL. 


\section{FLY-LEAF}

T(1)

\section{THE RECORD OF FAMILY FACULTIES.}

$B Y^{\prime}$

FRANCIS GALTON, F.R.S.

Mr. Francis Galton offers $£ 500$ in prizes to those British subjects resident in the United Kingdom who shall furnish him before May I 5, I 884, with the best Extracts from their own Family Records.

These Extracts will be treated as confidential documents, to be used for statistical purposes only, the insertion of names of persons and places being required solely as a guarantee of authenticity and to enable Mr. Galton to communicate with the writers in cases where further question may be necessary.

The value of the Extracts will be estimated by the degree in which they seem likely to facilitate the scientific investigations described in the preface to the Record of Family Faculties. ${ }^{1}$

More especially:

(a) By including every direct ancestor who stands within the limits of kinship there specified.

(b) By including brief notices of the brothers and sisters (if any) of each of those ancestors. (Importance will be attached both to the completeness with which each family of brothers and sisters is described. and also to the number of persons so described.) is based.

(c) By the character of the evidence upon which the information

(d) By the clearness and conciseness with which the statements and remarks are made.

The Extracts must be legibly entered either in the tabular forms contained in a duplicate copy of the Record of Family Faculties, (into

1 Record of Family Faculties, (consisting of tabular forms and directions for entering data, with an explanatory preface,) by Francis Galton, F.R.S. Macnillan \& Co., I884.

Works on similar subjects by the same author, and issued by the same publishers :-

Inquiries into Human Faculty and its Development, I 883.

English Men of Science, their Nature and their Nurture, 8874.

Hereditary Genius, its Lazes and Consequences, 1869.

To these may be added the following, as one in which the author has taken part :-

Lifc History Album, prepared by the direction of the Collective Investigation Committee of the British Medical Association. Edited by F. Galton, Chairman of the Life History Sub-Committee, I 884 . 


\section{FLY-LEAF TO THE RECORD OF FAMILY FACUL,TIES.}

which, if more space is wanted, additional pages may be stitched,) or they may be written in any other book with pages of the same size as those of the Record, provided that the information be arranged in the same tabular form and order. (It will be obvious that uniformity in the arrangement of documents is of primary importance to those who examine and collate a large number of them.)

Each competitor must furnish the name and address of a referee of good social standing (magistrate, clergyman, lawyer, medical practitioner, \&c.), who is personally acquainted with his family, and of whom inquiry may be made, if desired, as to the genera! trustworthiness of the competitor.

The Extracts must be sent prepaid and by post, addressed to Francis Galton, 42 Rutland Gate, London, S.W. It will be convenient if the letters "R.F.F." (Record of Family Faculties) be written in the left-hand corner of the parcel, below the address.

The examination will be conducted by the donor of the prizes, aided by competent examiners.

The value of the individual prizes cannot be fixed beforehand. No prize will, however, exceed $£, 50$, nor be less than $£ 5$, and $£ 500$ will, on the whole, be awarded.

A list of the gainers of the prizes will be posted to each of them. It will be published in one or more of the daily newspapers, also in at least one clerical, and one medical journal.

** The above conditions are in lieu of those provisionally sketched out by Mr. Galton in the Fortnightly Revieru of August, I88 3 , for the purpose of eliciting suggestions, and which were subsequently submitted in a more elaborate form to many members of the medical profession. Their present shape is fixed in accordance with the balance of opinions elicited by these preliminaries, which was in favour of throwing them open to general competition, and not to medical men only, as at first intended.

Mr. GaLton would add, that extracts from the Records of any family would be very acceptable to him, even such as may be too incomplete in the opinion of their authors to have the chance of gaining a prize, or which for any other reason should have the words, "not for competition," written upon them.

He sincerely trusts that his efforts to draw the attention of the public to the utility of family records, to induce them to rescue facts that are steadily gliding into oblivion, and to collect materials for serious scientific study, will be taken in good part and in the spirit in which they are made. 


\section{RECORD OF FAMILY FACULTIES.}

THis book is designed for those who care to forecast the mental and bodily faculties of their children, and to further the science of heredity.

The natural gifts of each individual being inherited from his ancestry, it is possible to foresee much of the latent capacities of a child in mind and body, of the probabilities of his future health and longevity, and of his tendencies to special forms of disease, by a knowledge of his ancestral precedents. When the science of heredity shall have become more advanced, the accuracy of such forecasts will doubtless improve; in the meantime we may rest assured that fewer blunders will be made in rearing and educating children, under the guidance of a lnowledge of their family antecedents, than without it.

Equal attention is directed in this book to the claims of every ancestor in the same degree of kinship. No countenance is given to the vanity that prompts most family historians to trace their pedigree to some notable ancestor, and to pass the rest over in silence. It demands an equal recognition of all the lines. We should remember the insignificance of any single ancestor in a remote degree. In the fourth generation backwards there are'sixteen ancestors, from whom the child receives on the average an equal inheritance. In the fifth there are thirty-two. One ancestor who lived at the time of the Norman Conquest, twenty-four generations back, contributes (on the supposition of no intermarriage of kinsfolk) less than one part in $16,000,000$ to the constitution of a man of the present day.

I found when making photographic composites of persons of the same race, that the change of one component in a group of eight different portraits rarely made any appreciable difference in the compound result. I infer that if the father of a family of children collects all the required data concerning his own parents and grandparents, and similarly those concerning the parents and grandparents of his wife, then it is probable in most cases that their chikdren, being informed about all their 


\section{RECORD OF FAMILY FACUI,TIES.}

ancestry up to their eight great-grandparents inclusive, will be equipped with almost as much hereditary information as they can need. But when an alien element of race or disease has been introduced into the family, its influence lasts longer; so that a dash of Hebrew or even of Huguenot blood may be traced far beyond the great-grandchildren, and has often been found to exercise a notable and valuable influence upon numerous descendants.

There is, also, something of much importance to be added about the brothers and sisters, uncles and aunts, and great-uneles and great-aunts of the two parents. Brothèrs and sisters are alike in blood, but it commonly happens that one of them exhibits some faculty in a conspicuous degree, which exists only in a latent form in another, and which the latter is perhaps equally capable of transmitting to his children. Therefore records of the faculties of the brothers and sisters of the direct ancestors are of great value in disclosing hidden characteristics.

The biological history of half-blood relatives is of secondary importance. Consequently, I lave left no place for cousins in this book, though, of course, the writer in it can interleave fresh pages to receive what entries he pleases.

If the custom of recording family faculties should become common, stores of information will be called into existence from which future inquirers into heredity may have the good fortune to draw copious supplies. I have found great willingness among correspondents to impart family information, when they are assured that it will be used for statistical purposes only, but the comprehensive family information which is now especially needed for scientific stucly and which, it is hoped, these records will collect, has never yet been brought together, and therefore does not at present admit of being imparted. The advance of the science of heredity is seriously delayed through the want of such data. We do not yet know whether any given group of different faculties which may converge by inheritance upon the same family will blend, neutralise, or intensify one another, nor whether they will be metamorphosed and issue in some new form. Our ignorance is especially great in hereditary maladies, where much alarm undoubtedly exists which inquiry will dispel. It is possible that the different disease tendencies of different ancestors may in some cases neutralise one another, and on the other hand, that some ancestral combinations may be far more hurtful to the descendants 
RECORD OF FAMILY FACULTIES.

than we have at present any idea of. The occasional anomaly of healthy children being born of unhealthy parents, and of weakly children being born of robust parents, admits of no other explanation. Our present ignorance of the conditions by which the level of humanity may be raised is so gross, that I believe if we had some dictator of the Spartan type, who exercised absolute power over marriages, assigning $A$ to be the wife of $B$, and $C$ to be the wife of $D$, and who ac:ed with the best intentions, he might possibly do even more harm than good to the race.

The following diagram shows in a compact form the direct ancestors with whom any group of brothers and sisters are most nearly connected, the group in question being described in the diagram by the word "Children." Besides the direct ancestors, the brothers and sisters of each of them have also to be taken into account, for the reasons already given :-

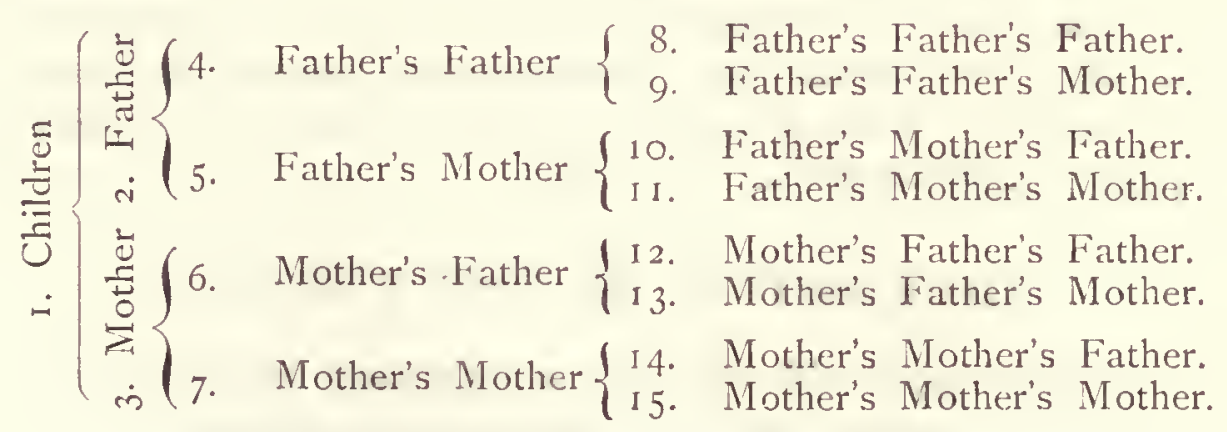

When preparing to fill the Tables, the writer should first determine his own position in the pedigree.

1. Suppose the writer to be male, and that he is the father of a young family; - then his own place will be "Father," and that of his wife will be "Mother;" the "Father's Father's Father" will be his own Father's Father, and so on.

2. Suppose he is unmarried;- - then he may class himself as one of the "Children;" in which case the "Father's Father's Father," will be his oivn Great-grandparent. Otherwise, if he has. a married brother or sister who have children, he may regard his brother as the "Father," or his sister as the "Mother," and his own place will be that of a "Father's Brother," or of a "Mother's Brother," as the case may be. 


\section{RECORD OF FAMILY FACULTIES.}

3. Suppose one or more of his own children are married and have families; then he may select one or other of his sets of grandchildren, as the "Children" of the pedigree, and work upwards from them.

4. Suppose the writer to be female; - then similar conditions to those in 1,2 , and 3 , will be applicable, with obvious modifications.

It will be noticed that $I$ have assigned a descriptive number to each ancestor; these will be found convenient for reference, and less confusing than the cumbrous verbiage of "Father's Mother's Father," and the like. The principle on which the numbers have been given is such, that they have useful and interesting properties, and that the method admits of indefinite extension. ${ }^{1}$ If we except No. 1 , which means "a child," without distinction of sex, every even number refers to a male, and every odd number to a female; thus 2 is the father, 3 is the mother. Again, if we double the descriptive number of any person, we obtain that of his father, which by the addition of I becomes that of his mother; thus, the father and mother of 2 are respectively 4 and 5, those of 5 are 10 and II. Every number contains, for those who care to analyse it, a complete history of the place in the genealogical tree of the ancestor to whom it belongs.

\section{DESCRIPTION OF THE TABLES.}

The Tables begin with an Index to Ancestors, which explains itself. As the record progresses and the Index is simultaneously filled up, the eye will divell upon the gaps that remain, and the writer will feel himself stimulated to obtain the deficient information, The next fifteen tables are separately headed and numbered in accordance with the diagram. Blank pages may be interleaved by the writer in them whenever he requires additional space, or wishes to introduce photograplss which add much to the interest and value of family records. A blank page is interposed between the Table of the Father and that of the Mother, as more space is sure to be required for their records than can be found in the printed forms.

Page $I$ is for a list of the Children in the Order of their Birth, and is intended to serve much the same purpose as the blank pages in a family

'See a short memoir by myself on the "Arithmetic Notation of Kinship," Vature, Sept. $6,188_{3}$. 
RECORD OF FAMLY FACULTIES.

Bible. It would contain more notice of infantile events than can be inserted in the tables that form the bulk of the volurne. However, each child when he grows old enough should have one of the latter tables all to hiniself.

I would here point out the propriety of assigning to every child some such book as the Life. History Album, ${ }^{1}$ prepared by the Collective Investigation Committee of the British Medical Association. The album is intended to serve as a register of the current events of a life from childhood onwards, so far as they are connected with development and health. If the register is faithfully kept, the album will serve the child in good stead the older he grows, and will be an advantage to his children after him. It will contain a large amount of detail, an abstract only of which could be inserted in this Record of Family Faculties, which is intended to bring together in a compact form the biological histories of many near relatives, and cannot, in consequence, afford space for more than brief notices of each of them.

Pages 2-15. Each of these pages is assigned to one of the fourteen direct ancestors specified in the foregoing diagram, and in the same numerical order, and is intended to be headed by his name. In other respects they are nearly alike and contain a series of questions. The object gained by answering them is threefold: the personal interest to the family in having the replies put upon record, the light they may throw on ancestral peculiarities which may be serviceable to the writers, and the statistical use to which they may be put by scientific inquirers. I will explain them from the latter point of view, as practically including the whole of the three.

(1) Date of birth and (16) that of death are plain facts admitting of verification and serving to identify, and to give the age at death of each member of the family, by which the family tendency to longevity or otherwise is measured.

(2), (3) Birthplace and residence are partial indications of race and origin, which; if confirmed by the surname, the personal characteristics, and other data, would justify the inquirer in sorting the replies into groups. Out of a large number of returns it would not be difficult to pick out several

${ }^{1}$ Life History Album, prepared by direction of the Collective Investigation Committee of the British Mledical Association, edited by Francis Galton, F.R.S., Chairman of the Life History Sub-Committee (Macmillan and Co., 1884). 


\section{RECORD OF HAMILY FACULTIFS}

examples in which the birthplaces, names, residences, and personal characteristics of the ancestry showed a great preponderance of such elements as Scotch, Irish, Welsh, Saxon, Danish, or Norman, and these should be treated separately from one another and from those in which the ancestry was variously mixed. Errors would sometimes occur in the sorting of individual cases, but the statistical results might be expected to lead to trustworthy conclusions.

A question is added as to the "origin" of each of the greatgrandparents. If there is any known peculiarity in their race, or any infusion of alien blood, it should be noted here.

(3), (4) The ages at marriage of the two parents, the number and the duration of life of the children, would enable inquiry to be made into fertility as associated with different admixtures of race or of diseasetendencies. TVe have yet to learn the conditions under which some families are prolific in their various branches, and others die out. If we should be able to contrast large batches of well-marked cases, a discussion of their family antecedents would throw much light on those conditions. The ages at death of the children would be entered thus, "A. G. 5; L. R. G. IO; M. G. 55," \&c. ; the initials first, and the age at death after.

(5) The mode of life, so far as it affects growth or health, would, if known, throw light on the effect of nurture over nature. We require to sclect the families in each of which there had been a noticeable difference in the mode of life of two or more of its members, and to cross divide those members into two groups, in one of which the mode of life had been healthy, the other in which it had been the reverse. Then by contrasting these groups we should see the relative effects of good and bad nurture on the devclopment of body and mind, and on the health, fertility, and duration of life.

(6) Was early life laborious? Why and how? This is intended to elicit evidence as to whether those who were hard-worked in boyhood, youth, and early manhood, have less robust children and grandchildren than those who led easier lives and married at the same ages. The queries "how and why" are important. The "how" will distinguish various forms of mental fret and exhaustion from one another and from muscular fatigue. The answer to "why" will distinguish laborious life due to the calls of duty, or to emulation, from that due to insufficiency of means during early married life. In the latter case especially it is to 


\section{RECORD OF FAMILY FACULTIES.}

be presumed that the children suffered from want of nourishment both before and immediately after their births.

(7) Height, when adult. This affords some confirmatory indication of race; it may also give a clue to differences in nurture in the same family, and should be considered in conjunction with the subject of the last paragraph. Whenever measurements have been made and recorder at the time, they are of course the most desirable data; it should be stated whether they were made with the shoes on or off. But when there is no other guide beyond what memory affords of the general appearance, such terms as tall, very tall, middle height, \&c., must be used instead. Any accessible facts concerning the stature at different ages should be recorded.

Colour of Hair when adult. Experience shows that the medium tints are not recorded in a uniform manner, but that persons are apt to consider the medium tint in their locality as that of England generally. Thus the same hair would be differently named by a man in Devonshire and by one in Glasgow; a tint that would seem light to the first would seem dark to the second. The hair of children darkens considerably as they grow older, even up to the time when it begins to turn grey. The colour of such locks of hair as may have been preserved as mementos is apt to fade and those that have been worked into bracelets and lockets are usually coloured artificially. Much judgment has in consequence to be exercised before making these returns. Decided cases of dark and of fair hair and eyes, such as "hair dark, eyes hazel or black," or "hair light, eyes blue or gray," are more exempt from these sources of error, and are proportionately valuable.

The Colour of the Eyes is more persistent throughout life than that of the hair.

The colour of the hair is of interest in connection with the question which has been raised whether the English race as a whole is not becoming more dark-haired. There is no à priori improbability in the fact. The recent and rapid changes in English habits must have caused certain sub-types to prevail in the struggle for existence, that were repressed before, and it is of interest to know what these sub-types are. The colour of the hair of animals is often found to be intimately correlated with their power or incapacity to thrive under certain conditions, and it may well be the same in the case of man. Again, it is undoubtedly the fact 


\section{RECORD OF FAMILY IACULTIES.}

in America, ${ }^{1}$ where the mental fidget, social worry, business anxiety, and other conditions that characterise modern eivilisation, are even more pressing than with us, that black-haired persons are less liable to permanent ill-effects from nearly every form of disease, than those who are fair-haired.

It would be easy to discover from an analysis of a considerable number of family records.-

(a) Whether it be true that children born during a recent period in England are darker than their parents.

(b) Whether there is any change in other personal characteristics.

(c) Whether dark-haired and other types differ in fertility.

(d) Whether the English race as a whole, is becoming more darkhaired or otherwise changed, as the outcome of two possibly opposing tendencies, namely, of the most enduring type being the least prolific.

(8) General appearance. The answer to this question, which would include a statement as to weight at various ages, would usefully supplement the other eviclences concerning race and development which have been mentioned. A list of the best extant photographs or portraits of the person at various ages, might be written out, and a selection from them inserted on an interleaved page.

(9) Bodily strength and energy, if much above or below the average. Facts by which these may be illustrated are very much more to be desired than general assertions. The statement that a person had won prizes in such and such a competition, that he had accomplished such and such feats of strength and endurance, that his daily occupation or amusement consisted in so much walking, and the like, is a measurement of some exactitude and one that admits of verification. But merely to say that a man is very strong and energetic, is an assertion that is too deficient in definition, and is a mere opinion that others may not share. Similarly as regards notable weakness.

(10) Keenness or imperfection of sight and other senses. These inquiries refer to colour-blindness and to all those faults of sight in youth which have to be remedied by speetaeles; they should be defined, and the age when they were first observed, stated. They are hereditary and are also much affected by nurture. Keenness of sensation in each of its forms is a valuable natural gift, unfortunately no means are as yet easily

J J. H. Baxter, Statistics Mcdical and Anthropoiogical, Washington, 1875 . 


\section{RECORD OF FAMILY FACULTIES.}

accessible for testing it in different persons; there are no anthropometric laboratories as yot in existence to which any one may go, and on payment of a small fee have all his faculties measured and registered by the various ingenious appliances known to modern science. We must therefore be content for the present with such definite facts bearing on the keenness or imperfection of the various senses as may have been incidentally observed.

(1 I) The mental powers, like the bodily ones, must be measured by achievement; relatively as in competition with others, or absolutely by the amount and quality of intellectual work actually accomplished. Facts bearing on precocity or on the slow development of the mental powers, deserve mention.

(12) Character and temperament. Nearly every individual is notable for some peculiarity of mind or disposition, and in some few persons the sanguine, melancholy, nervous, or lymphatic temperament is well marked. All such peruliarities should be noted as they are strongly hereditary and may throw much light on the faculties of the family. Moreover the study of them is peculiarly attractive.

(I3) Favourite pursuits, and interests, and artistic capacities, are facts useful to record as being definite expressions of character and temperament.

We now come to the medical data which rank as the most important of all in statistical investigations into the rise and fall of families. Medical men are in an excellent position to supply these in respect to their own families. They know precisely what is wanted and how to express it. They have less of that shrinking from putting maladies on record which most persons feel even against their better judgment, because they are habituated to read and write medical cases. Moreover, they can obtain medical facts concerning members of their own families more easily than other people, being on freer terms with their professional brethren.

(14) Minor ailments. A knowledge of these gives considerable help towards understanding the "constitution" of a person, and it is a matter of great interest to learn the connection between the family tendency to minor and to graver maladies. The former may be outlets and safety valves to prevent the occurrence of the latter. Among 
RECORD OF FAMILY FACULTIES.

them are ( $I$ take this list and that in the next paragraph from the Life History Album already alluded to):-

Colds in the head or throat, sick headaches, sleeplessness, boils, quinsy, enlarged glands in the neck, bleeding at the nose, indigestion, bilious attacks (state whether accompanied by jaundice, vomiting, or headache), constipation, skin eruptions (their nature should be stated if known), varicose veins, \&c.

Malformations, which are extremely hereditary, should be included under this or under the following head.

(15) Graver illnesses. The existence of one or more of the following diseases in any members of the family should be recorded, and the age at which it first appeared:-

Gout, rheumatism, consumption, spitting of blood, struma (scrofula), cancer (and other forms of tumour), bronchitis, asthma, paralysis (state whether of both legs or of one side), epilepsy, insanity, heart-disease, dropsy of abdomen, general dropsy (Bright's discase), diabetes, stone, goître, fistula, the peculiar liability to bleed seriously from slight cuts, \&c.

(16) Cause and date of death. Some remarks will be made in the next paragraph on the registered causes of death. These statements are far from being as trustworthy as desirable, words of ill-omen being avoided for fear of wounding the family feeling, and the secondary symptoms of a grave disorder being often registered instead of the primary one. Still, the registered cause of death, wherever found, is at piece of information that has always some value, as it generally indicates the seat of the malady and supplies negative evidence, but it should be supplemented if possible by the results of independent and careful inquiries.

\section{Documentary Evidence.}

There is no difficulty in ascertaining the registered cause of death of any person in England or Wales since the middle of the year 1837 , in Scotland since the beginning of 1855 , and in Ireland since the beginning of 1864 , by making application at the General Register Offices in London, Edinburgh, and Dublin respectively.

The formalities, fees, and information given, are much the same in all three cases. I give those of the General Register Office, Somerset House, London, as an example. 
RECORD OF FAMLLY FACULTIES.

Every death is registered in the following form :-

1837.-Deaths in the District of Marylebone, North, in the county of Middlesex.

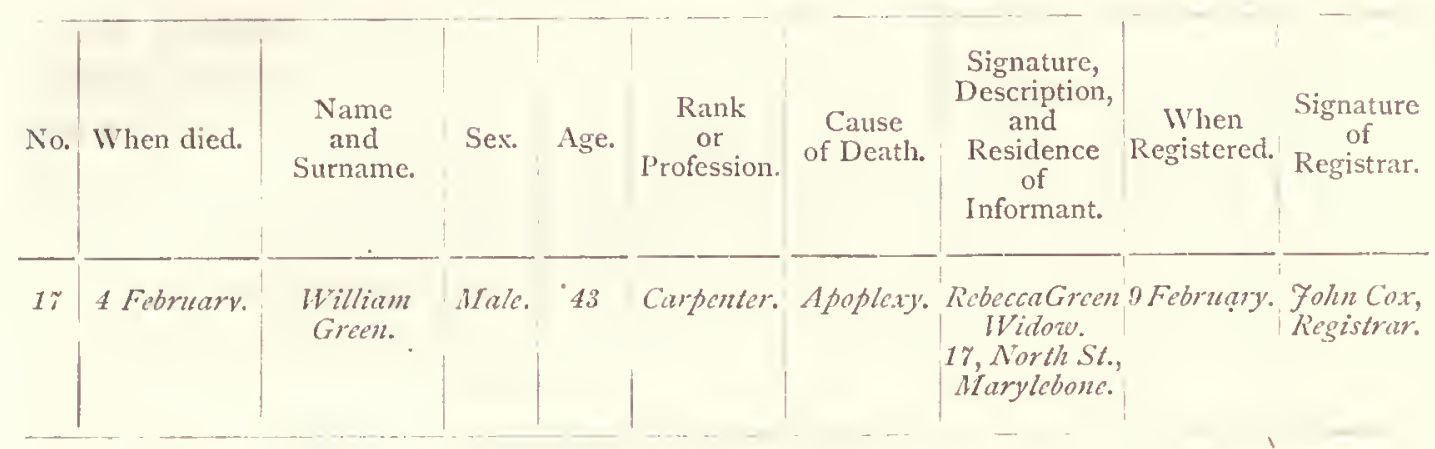

The words and figures in italics are filled up in the schedules as the case may be, and the registers are well indexed, so that with but imperfect knowledge of such facts as the full name, the date of death, and the place of death, it is possible to hunt out the required entry with facility. The fees are for a "Particular Search," that is for a search over any period not exceeding five years for any given entry, is. ; for a "General Search," that is, during any number of successive hours not exceeding six, without stating the object of the search, $\&_{1}$. There are no printed rules concerning memoranda, but the applicant is not prevented from taking a few rapid pencil notes. The charge for a certified and stamped copy of an extract is $2 s .7 d$.

Scarches and certificates of births or of marriages are regulated by the same conditions. The latter give the name and surname of the father of the husband and those of the father of the wife, and their respective ranks or professions. It also gives the rank and profession of the husband.

Documentary evidence of Births, Deaths, and Marriages, prior to the dates above mentioned, is to be obtained from Parochial registers, when the place where the event took place is known.

A record is kept at the India Office, of Europeans who have died in India, together with the causes of their death.

Wills may also afford means of supplementing missing data. If they were proved in the province of Canterbury, they are easily accessible at Doctors' Commons. 


\section{RECORD OF FAMILY FACULTIES.}

Entries in family bibles, old letters, and the numerous miscellaneous documents which are treasured up in families, often give most valuable assistance in genealogical inquiries.

It is quite impossible in a brief space to describe the many documentary records that may exist concerning any person. Among these are School registers, those of matriculation at the Universities, polling books, directories, the army and especially the navy registers. It is very probable that the main facts of the career of any given person who is known to have resided in England and to have been alive within the present century can be traced, if pains be taken to search for them.

\section{Brothlrs anil Sisters of Direct Ancestors.}

The twelve pages that follow p. 15 are similarly arranged to those which have just been described, except that more of their heading is left to be filled up in pen and ink. The number of brothers and sisters of each of the fourteen kinds of ancestors is so variable, and the completeness with which their history is likely to be known is so different, that it is impossible to prepare more methodical tables for their entry without great waste of space. If the writer wants more pages, he can easily interleave then; and-he need not copy the various questions upon them, but only their numbers.

A little further on are more compact sets of Tables for the same purpose. They are so arranged that the entries of the brothers will be separated from those of the sisters. It will have been observed that a similar separation of sons from daughters has been made elsewhere. There are good reasons for this: first, it prevents the possibility of a mistake in sex; secondly, the data concerning males have ultimately to be separated from those concerning females-tlius, it would be absurd to mingle the heights of brothers and sisters to deduce an average from them; thirdly, there is a considerable tendency in heredity to follow sex, the males of a family often having a prevalence of some one characteristic, and the females a different one.

\section{Summaries.}

Blank forms for summaries are given that admit of being variously filled; they are arranged on the same principle as the Inclex to 


\section{RECORD OF FAMILY FACUL'TIES.}

Ancestors already described. The first might contain page, initials, height, and colour of hair; thus:-12, F.N. short, v. dark. In this way a general view will be obtained of the variety of racial characteristics in the ancestry; how far the breed is pure, and how far mixed.

A second summary might be of page, initials, disease or cause of death, and age at death; thus:-I6 A.B. apoplexy, d. 56.

Other summaries may be added at the discretion of the writer. These synoptic views of the family will be usually found to bring its biological unity into startling relief. It is impossible after looking at many of them, to doubt that a knowledge of ancestral precedents enables a far more accurate forecast to be made of the future of a child than would be otherwise possible.

Arpendices. The book closes with three appendices.

I. On the biological history and hereditary peculiarities of mind and body on the father's side of the family.

II. Similarly on the mother's side.

III. An examination of the way in which the faculties of the father and mother are blended or otherwise combined in the child.

The inquiries I wish to set in motion by means of this publication, throughout many families, are such as relatives and friends will gladly assist in making. The memories of ladies are excellent repositories of personal matters, dates, and other details; a family inquiry greatly interests them, and they are zealous correspondents. Whatever may be the value of the results, the facts incidentally obtained during the course of the inquiry will form a separate document much prized by all the family.

The scientific importance of each investigation will, however, be soon appreciated by the author of it, for his researches will lay bare many farreaching biological bonds that tie his family into a connected whole, whose existence was previously little suspected. Few, if any, have seriously studied the facts of heredity without becoming impressed with the conviction that no man stands on an isolated basis, but that he is a prolongation of his ancestry in no metaphorical sense, and I shall be surprised if the compilation of these registers does not extend this conviction very widely.

FRANCIS GALTON. 


\section{INDEX TO ANCESTORS.}

Page.

Niane.

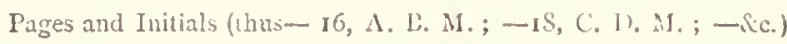

Father $=\ldots . . .$. his $\left\{\begin{array}{l}\text { brothers. } \\ \text { sisters. }\end{array}\right.$

l. [................. his $\left\{\begin{array}{l}\text { brothers. } \\ \text { sisters. }\end{array}\right.$

I. M. 5 . . . . . . . . . her $\left\{\begin{array}{l}\text { brothers. } \\ \text { sisters. }\end{array}\right.$

F. F. F. . . . . . . his $\left\{\begin{array}{l}\text { brothers. } \\ \text { sisters. }\end{array}\right.$

F. I. M. . . . . . . . . her $\frac{\text { brothers. }}{\text { sisters. }}$

I. M. I. 10............ his $\left\{\begin{array}{l}\text { brothers. } \\ \text { sisters. }\end{array}\right.$

F. 11. M. II . . . . . . . her $\left\{\begin{array}{l}\text { brothers. } \\ \text { sisters. }\end{array}\right.$

Mother 3................ her / $\int_{\text {sisters. }}^{\text {brothers. }}$

NI. F. G

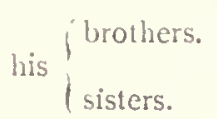

M. M.

M. F. T. 12. . . . . . . his $\left\{\begin{array}{l}\text { brothers. } \\ \text { sisters. }\end{array}\right.$

M. F. M. 13 . . . . . . . her $\left\{\begin{array}{l}\text { brothers. } \\ \text { sisters. }\end{array}\right.$

M. M. F. I4 . . . . . . . his $\left\{\begin{array}{l}\text { brothers. } \\ \text { sisters. }\end{array}\right.$

M. M. M. 15 . . . . . her $\left\{\begin{array}{l}\text { brothers } \\ \text { sisters. }\end{array}\right.$ 


\section{CHILDREN IN ORDER OF BIRIH.}

Each child when he grows old enougin, should have a separate page assigned to him or to her, of those subsequerit to page $\mathrm{r}_{5}$.

I)ate of Birth,

Name.

Larly Memoramlia.

See Page.

$\zeta, j$,

ese

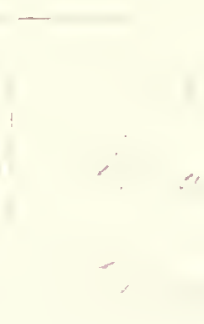


I. Date of birth.

2. Occupation.
Birthplace.

Residences.

3. Age at The place for this entry is mariage. $\}$ at 4 in next printed page.

4. do. of wife $\left\{\begin{array}{l}\text { The place for this entry is } \\ \text { at } 3 \text { in next printed page. }\end{array}\right.$

5. Mode of life so far as affecting growth or health.

6. Was early life laborious? why and how ?

7. Adult height.

8. Gencral appearance.

9. Bodily strength and energy, if much above or below the average.

I o. Keenness or imperfection of sight or other senses.

11. Mental powers and energy, if much above or below the average.

I 2. Character and temperament.

I3. Favorite pursuits and interests.

Artistic aptitudes.

14. Minor ailments to $f$ in youth. which there was special liability (in middle age.

I5. Graver illnesses $\left\{\begin{array}{l}\text { in youth. } \\ \text { in middle age. }\end{array}\right.$

16. Cause and date of death, and age at death.

I. General remarks. 

I. Date of birth.

Birthplace.

2. Occupation.

Residences.

\begin{tabular}{|c|c|c|c|}
\hline 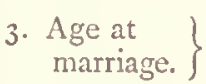 & Total & sons & $\left.\begin{array}{l}\text { No. of sons } \\
\text { deceased. }\end{array}\right\}$ \\
\hline $\left.\begin{array}{c}\text { 4. ditto of } \\
\text { husband }\end{array}\right\}$ & & daus. & $\begin{array}{l}\text { No. of daus. } \\
\text { deceased. }\end{array}$ \\
\hline
\end{tabular}

5. Mode of life so far as

affecting growth or health.

6. Was early life laborious? why and how?

7. Adult height.

Colour of hair when adult.

Colour of eyes.

8. General appearance.

9. Bodily strength and energy, if much above or below the average.

זo. Keenness or imperfection of sight or other senses.

Ix. Mental powers and energy, it much above or below the average.

r. Character and temperament.

r3. Favorite pursuits and interests,

Artistic aptitudes.

r4. Minor ailments to (in youth. which there was

special liability (in middle age.

55. Graver illnesses $\left\{\begin{array}{l}\text { in youth. } \\ \text { in middle age. }\end{array}\right.$

r6. Cause and date of death, and age at death.

I7. General remarks. 


\section{FATHER'S FATHER}

I. Date of birth.

Birtliplace.

2. Occupation.

Residences.

3. Age at The place for this entry

marriage. $\}$ is at 4 in next page.

4. do. of wife $\} \begin{aligned} & \text { The place for this entry } \\ & \text { is at } 3 \text { in next page }\end{aligned}$

5. Mode of life so far as

affecting growth or health.

6. Was early life laborious? why and how?

7. Adult height.

Colour of hair when adult.

Colour of eyes.

8. General appearance.

9. Bodily strength and energy, if much above or below the average.

ı०. Keenness or imperfection of sight or other senses.

II. Mental powers and energy, if much above or below the average.

12. Character and temperament.

13. Favorite pursuits and interests.

Artistic aptitudes.

14. Minor ailments to $\int$ in youth. which there was special liability (in middle age.

I5. Graver illnesses $\left\{\begin{array}{l}\text { in youth. } \\ \text { in middle age. }\end{array}\right.$

16. Cause and date of death, and age at death.

17. General remarks 
I. Date of birth.

Birthplace.

2. Occupation.

Residences.

3. Age at marriage.

4. ditto of $\}$ husband $\}$

Total $\left\{\begin{array}{l}\text { sons } \\ \text { No. of }\end{array}\right.$

$\left.\begin{array}{l}\text { No. of sons } \\ \text { deceased. }\end{array}\right\}$

No. of daus. $\}$ $\left.\begin{array}{l}\text { No. of daus. } \\ \text { deceased. }\end{array}\right\}$ ages

ages

5. Mode of life so far as affecting growth or health.

6. Was early life laborious? why and how?

7. Adult height.

Colour of hair when adult.

Colour of eyes.

8. General appearance.

9. Bodily strength and energy, if much above or below the average.

10. Keenness or imperfection of sight or other senses.

II. Mental powers and. energy, if much above or below the average.

12. Character and

temperament.

13. Favorite pursuits and interests.

Artistic aptitudes.

14. Minor ailments to $($ in youth. which there was
special liability (in middle age.

15. Graver illnesses $\left\{\begin{array}{l}\text { in youth. } \\ \text { in middle age. }\end{array}\right.$

16. Cause and date of death, and age at death.

17. General remarks. 
I. Date of birth.

2. Occupation.
Birthplace.

Residences.

3. Agre at The place for this entry

marnage. $\}$ is at 4 in next page.

4. do.of wife $\} \begin{gathered}\text { The place for this entry } \\ \text { is at } 3 \text { in next page }\end{gathered}$

5. Mode of life so far as

affecting growth or health.

6. Was early life laborious? why and how?

7. Adult height.

Colour of hair when adult.

Colour of eyes.

8. General appearance.

9. Bodily strength and energy, if much above or below the average.

ro. Keenness or imperfection of sight or other senses.

II. Mental powers and energy, if much above or below the average.

12. Character and temperament.

13. Favorite pursuits and interests.

Artistic aptitudes.

14. Minor ailments to $\int$ in youth.

which there was

special liability (in middle age.

15. Graver illnesses $\left\{\begin{array}{l}\text { in youtl. } \\ \text { in middle age. }\end{array}\right.$

16. Cause and date of death, and age at death.

17. General remarks. 
1. Date of birth.

Birthplace.

2. Occupation.

Residences.

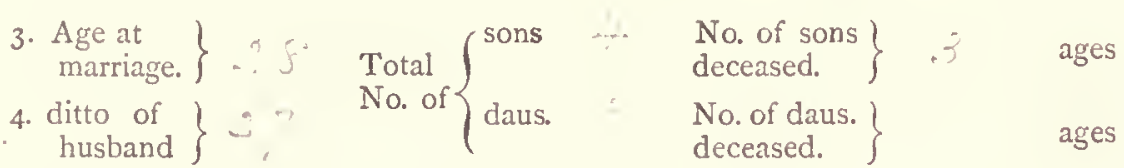

5. Mode of life so far as affecting growth or health.

6. Was early life laborious? why and how?

7. Adult height.

Colour of hair when adult.

Colour of eycs.

8. Gencral appearance.

9. Bodily strength and energy, if much above or below the average.

ro. Keenness or imperfection of sight or other senses.

II. Mental powers and energy, if much above or below the average.

I 2. Character and temperament.

13. Favorite pursuits and interests.

Artistic aptitudes.

r. Minor ailments to (in youth.

which there was
special liability in middle age. $, \ldots, d, c_{2}$

15. Graver illnesses $\{$ in middle age.

16. Cause and date of death, and age at death.

17. General remarks. 


\section{FATHER'S FATHER'S FATHER}

I. Date of birth.

2. Occupation.
Birthplace and origin.

Residences.

3. Age at $\}$ The place for this entry marriage. $\}$ is at 4 in next page.

4. do. of wife $\} \begin{aligned} & \text { The place for this entry } \\ & \text { is at } 3 \text { in next page }\end{aligned}$

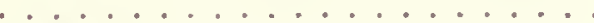

ร. Mode of life so far as affecting growth or health.

6. Was early life laborious? why and how?

7. Adult height.

Colour of hair when adult.

Colour of eyes.

8. General appearance.

9. Bodily strength and energy, if much above or below the average.

10. Keenness or imperfection of sight or other senses.

I1. Mental powers and energy, if much above or below the average.

I 2. Character and temperament.

13. Favorite pursuits and interests.

Artistic aptitudes.

14. Minor ailments to $($ in youth. which there was special liability (in middle age.

15. Graver illnesses $\{$ in middle age.

I6. Cause and date of death, and age at death.

17. General remarks. 
I. Date of birth.

2. Occupation.

$\left.\begin{array}{l}\text { 3. Age at } \\ \text { marriage. }\end{array}\right\}$

4. ditto of ?

husband $\}$

5. Mode of life so far as

aflecting growth or health.

6. Was early life laborious? why and how ?

7. Adult height.

Colour of hair when adult. $\left.\begin{array}{l}\text { No. of sons } \\ \text { deceased. }\end{array}\right\}$

No. of daus. ? deceased.
Birthplace and origin.

Residences.

8. General appearance.

o. Bodily strength and energy, if much above or below the average.

Io. Keenness or imperfection of sight or other senses.

II. Mental powers and energy, if much above or below the average.

I 2. Character and temperament.

13. Favorite pursuits and interests.

Artistic aptitudes.

14. Minor ailments to (in youth. which there was special liability (in middle age.

ages

ages 


\section{FATHER'S MOTHER'S FATHER}

I. Date of birth.

Birthplace and origin.

2. Occupation.

Residences.

3. Age at The place for this entry

marrage. is at 4 in next page.

4. do.ofwife The place for this entry

is at 3 in next page

5. Mode of life so far as

affecting growth or health.

6. Was early life laborious? why and how?

7. Adult height.

Colour of hair when adult.

Colour of eyes.

8. General appearence.

9. Bodily strength and energy, if much above

or below the average.

10. Keenness or imperfection of sight or other senses.

Ir. Mental powers and energy, if much above or below the average.

12. Character and temperament.

13. Favorite pursuits and interests.

Artistic aptitudes.

14. Minor ailments to $f$ in youth.

which there was

special liability (in middle age.

15. Graver illnesses $\left\{\begin{array}{l}\text { in youth. } \\ \text { in middle age. }\end{array}\right.$

16. Cause and date of death, and age at death.

I7. General remarks. 
I. Date of birth.

Birthplace and origin.

2. Occupation.

Residences.

$\left.\begin{array}{l}\text { 3. Age at } \\ \text { marriage. }\end{array}\right\}$

4. ditto of $)$

husband $\}$

Total $\begin{aligned} & \text { sons } \\ & \text { No. of }\end{aligned}$ claus.

No. of sons )

deceased. $\}$

ages

No. of daus.

deceased. $\}$

ages

5. Mode of life so far as affecting growth or health.

6. Was early life laborious? why and how?

7. Adult height.

S. General appearance.

9. Bodily strength and energy, if much above or below the average.

10. Keenness or imperfection of sight or other senses.

II. Mental powers and energy, if much above or below the average.

I 2. Character and temperament.

I3. Favorite pursuits and interests.

Artistic aptitudes.

14. Minor ailments to $\int$ in youth. which there was special liability $($ in middle age.

15. Graver illnesses

$$
\left\{\begin{array}{l}
\text { in youth. } \\
\text { in middle age. }
\end{array}\right.
$$

I6. Cause and date of death, and age at death.

I7. General remarks. 


\section{MOTHER'S FATHER'S FATHER}

I. Date of birth.

Birthplace and origin.

2. Occupation.

Residences.

$\left.\begin{array}{l}\text { 3. Age at } \\ \text { marrage. }\end{array}\right\} \begin{aligned} & \text { The place for this entry } \\ & \text { is at } 4 \text { in next page. }\end{aligned}$

4. do. of wife $\} \begin{gathered}\text { The place for this entry } \\ \text { is at } 3 \text { in next page }\end{gathered}$

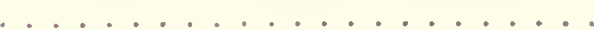

5. Mode of life so far as affecting growth or health.

6. Was early life laborious? why and how?

7. Adult height.

Colour of hair when adult.

Colour of eyes.

8. General appearance.

9. Bodily strength and energy, if much above or below the average.

10. Keenness or imperfection of sight or other senses.

Ir. Mental powers and energy, if much above or below the average.

12. Character and temperament.

I3. Favorite pursuits and interests.

Artistic aptitudes.

r. Minor ailments to $\int$ in youth. which there was
special liability (in middle age.

15. Graver illnesses $\left\{\begin{array}{l}\text { in youth. } \\ \text { in middle age. }\end{array}\right.$

16. Cause and date of death, and age at death.

I7. General remarks. 
I. Date of birth.

2. Occupation.

$\left.\begin{array}{l}\text { 3. Age at } \\ \text { marriage. }\end{array}\right\}$

4. ditto of ! husband $\}$
Birthplace and origin.

Residences.

$\left.\begin{array}{l}\begin{array}{l}\text { No. of sons } \\ \text { deceased. }\end{array} \\ \begin{array}{l}\text { No. of daus. } \\ \text { deceased. }\end{array}\end{array}\right\} \quad$ ages

5. Mode of life so far as affecting growth or health.

6. Was early life laborious? why and how?

7. Adult height.

Colour of hair when adult.

Colour of eyes.

8. General appearance.

9. Bodily strength and energy, if much above or below the average.

Io. Keenness or imperfection of sight or other senses.

II. Mental powers and energy, if much above or below the average.

1 2. Character and temperament.

r3. Favorite pursuits and interests.

Artistic aptitudes.

14. Minor ailments to in youth. which there was
special liability

r. Graver illnesses $\left\{\begin{array}{l}\text { in youth. } \\ \text { in middle age. }\end{array}\right.$

r6. Cause and date of death, and age at death.

r7. General remarks. 


\section{MOTHER'S MOTHER'S FATHER}

1. Date of birth.

Birthplace and origin.

2. Occupation.

Residences.

3. Age at The place for this entry marrage. $\}$ is at 4 in next page.

4. do. of wife $\} \begin{aligned} & \text { The place for this entry } \\ & \text { is at } 3 \text { in next page }\end{aligned}$

5. Mode of life so far as affecting growth or health.

6. IVas early life laborious? why and how?

7. Adult height.

Colour of hair when adult.

Colour of eyes.

S. General appearance.

9. Bodily strength and energy, if much above or below the average.

I 0. Keenness or imperfection of sight or other senses.

I I. Mental powers and energy, if much above or below the average.

12. Character and temperament.

13. Favorite pursuits and interests.

Artistic aptitudes.

14. Minor ailments to $($ in youth. which there was special liability (in middle age.

15. Graver illnesses $\left\{\begin{array}{l}\text { in youth. } \\ \text { in middle age. }\end{array}\right.$

16. Cause and date of death, and age at death.

17. General remarks. 
1. Date of birth.

Birthplace and origin.

2. Occupation.

Residences.

$\left.\left.\begin{array}{c}\text { 3. Age at } \\ \text { marriage. }\end{array}\right\} \quad \begin{array}{c}\text { Total } \\ \text { 4. ditto of } \\ \text { husband }\}\end{array}\right\} \begin{gathered}\text { sons } \\ \text { daus. }\end{gathered}$

$\left.\begin{array}{l}\begin{array}{l}\text { No. of sons } \\ \text { deceased. }\end{array} \\ \begin{array}{l}\text { No. of daus. } \\ \text { decensed. }\end{array}\end{array}\right\}$

ages

decensed.

ages

3. Mode of life so far as affecting growth or health.

6. Was early life laborious? why and how?

7. Adult height.

Colour of hair when adult.

Colour of eyes.

S. General appearance.

9. Bodily strength and energy, if much above or below the average.

ı. Keenness or imperfection of sight or other senses.

II. Nental powers and energy, if much above or below the average.

12. Character and temperament.

13. Favorite pursuits and interests.

Artistic aptitudes.

14. Minor ailments to (in youth. wlich there was special liability (in middle age

I5. Graver illnesses $\left\{\begin{array}{l}\text { in youth. } \\ \text { in middle age. }\end{array}\right.$

16. Cause and date of death, and age at death.

I. General remarks. 
In each of the following pages the "Place in the pedigree" should be entered, and the name of the person to whom the page is assigned should follow in the same line.

Example :-

Place in
pedigree brother of F. F. F. 8. Fohn Smith.

(The letters "F. F. F." stand here for "Father's Father's Father.") 
I. Date of birth.

Birthplace.

2. Oecupation.

Residences.

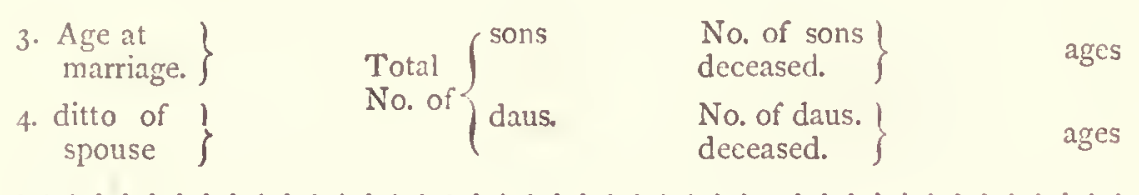

5. Mode of life so far as affecting growth or health.

6. Was early life laborious? why and how?

7. Adult height.

8. General appearance.

9. Bodily strength and energy, if much above or below the average.

10. Keenness or imperfection of sight or other senses.

II. Mental powers and energy, if much above or below the average.

I2. Chareter and temperament.

13. Favorite purstits and interests. Artistic aptitudes.

14. Ninor ailments to (in youth. which there was
special liability (in middle age. ......

15. Graver illnesses $\{$ in middle age.

16. Cause and date of death, and age at death.

17. General remarks. 
1. Date of birth.

Birthplace.

2. Occupation.

Residences.

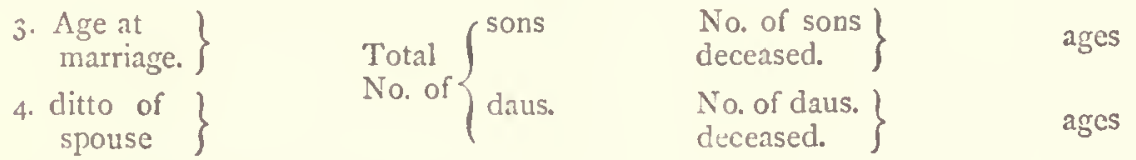

5. Mode of life so far as affecting growth or health.

6. Was early life laborious? why and how?

7. Adult height.

8. General appearance.

9. Bodily strength and energy, if much above or below the average.

10. Keenness or imperfection of sight or other senses.

1I. Mental powers and energy, if much above or below the average.

12. Character and temperament.

3. Favorite pursuits and interests.

Artistic aptitudes.

14. Minor ailments to (in youth. which there was special liability (in middle age.

15. Graver illnesses $\left\{\begin{array}{l}\text { in youth. } \\ \text { in middle age. }\end{array}\right.$

16. Cause and date of death, and age at death.

17. General remarks. 
1. Date of birth.

Birthplace.

2. Occupation.

Residences.

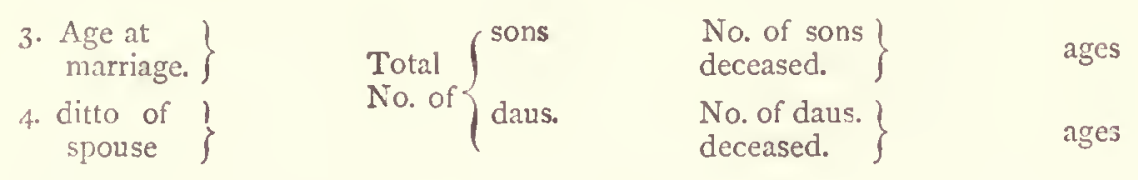

5. Node of life so far as affecting growth or health.

6. Was early life laborious? why and how?

7. Adult height.

8. General appearance.

9. Bodily strength and energy, if much above or below the average.

10. Keenness or imperfection of sight or other senses.

1I. Mental powers and energy, if much above or below the average.

12. Character and tcmperament.

13. Favorite pursuits and interests.

Artistic aptitudes. 14. Minor ailments to $\int$ in youth.
which there was special liability (in middle age.

15. Graver illnesses $\left\{\begin{array}{l}\text { in youth } \\ \text { in middle age. }\end{array}\right.$

16. Cause and date of dcath, and age at death.

17. General remarks. 
I. Date of birth.

Birthplace.

2. Occupation.

Residences.

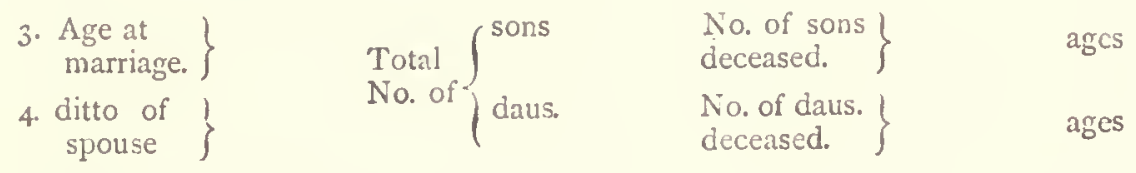

5. Mode of life so far as affecting growth or healtl.

6. Was early life laborious? why and how?

7. Adult height.

Colour of hair when adult.

Colour of eyes.

8. General appearance.

9. Bodily strength and energy, if much above or below the average.

ro. Keenness or imperfection of sight or other senses.

II. Mental powers and energy, if much above or below the average.

I2. Character and temperament.

r. Favorite pursuits and interests.

Artistic aptitudes.

I4. Minor ailments to $f$ in youth. which there was special liability

\rfloor in middle age.

15. Graver illnesses

$$
\left\{\begin{array}{l}
\text { in youth } \\
\text { in middle age. }
\end{array}\right.
$$

r6. Cause and date of death, and age at death.

I 7. General remarks. 
I. Date of birth.

Birthplace.

2. Occupation.

Residences.

\section{$\left.\begin{array}{l}\text { 3. Age at } \\ \text { marriage. }\end{array}\right\}$}

4. ditto of ? spouse $\}$

Total $\left\{\begin{array}{l}\text { sons } \\ \text { No. of }\end{array}\right.$

\section{No. of sons \\ No. of daus. ) deceased. $\}$}

ages

5. Mode of life so far as affecting growth or health.

6. Was early life laborious? why and how?

7. Adult height.

Colour of hair when adult.

Colour of eyes.

8. General appearance.

9. Bodily strength and energy, if much above or below the average.

10. Keenness or imperfection of sight or other senses.

II. Mental powers and energy, if much above or below the average.

2. Character and temperament.

¿3. Favorite pursuits and interests.

Artistic aptitudes.

14. Minor ailments to $\int$ in youth. which there was special liability $($ in middle age.

5. Graver illnesses $\left\{\begin{array}{l}\text { in youth. } \\ \text { in middle age. }\end{array}\right.$

16. Canse and date of dcath, and age at death.

17. General remarks. 
I. Date of birth.

Birthplace.

2. Occupation.

Residences.

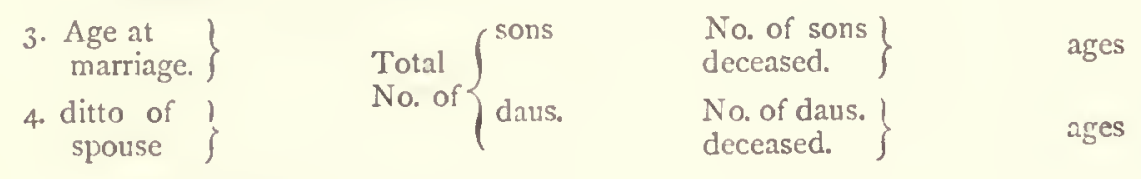

5. Mode of life so far as affecting growth or health.

6. Was early life laborious? why and how?

7. Adult height. Colour of hair when adult. Colour of eyes.

8. General appearance.

9. Bodily strength and energy, if much above or below the average.

ı. Keenness or imperfection of sight or other senses.

II. Mental powers and energy, if much above or below the average.

12. Character and temperament.

23. Favorite pursuits and interests.

Artistic aptitudes.

14. Minor ailments to $\int$ in youth.
which there was special liability / in middle age.

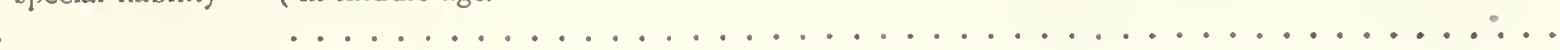

15. Graver illnesses $\left\{\begin{array}{l}\text { in youth. } \\ \text { in middle age. }\end{array}\right.$

16. Cause and date of death, and age at death.

7. General remarks. 
I. Date of birth.

2. Occupation.

$\left.\begin{array}{l}\text { 3. Age at } \\ \text { marriage. }\end{array}\right\}$

4. ditto of spouse $\}$
Birthplace.

Residences.

5. Mode of life so far as affecting growth or health.

6. Was early life laborious? why and how?

7. Adult height.

8. General appearance.

9. Bodily strength and energy, if much above or below the average.

ro. Keenness or imperfection of sight or other senses.

II. Mental powers and energy, if much above or below the average.

r2. Character and temperament.

13. Favorite pursuits and interests.

Artistic aptitudes.

14. Minor ailments to $($ in youth.

which there was

special liability (in middle age.

$\left.\begin{array}{l}\begin{array}{l}\text { No. of sons } \\ \text { deceased. }\end{array}\end{array}\right\} \quad$ ages

No. of daus.

dcceased. $\}$ 
Birthplace.

I. Date of birth.

Residences.

2. Occupation.

3. Age at marriage.

No. of sons

4. ditto of ? spouse $\}$

Total $\left\{\begin{array}{l}\text { sons } \\ \text { No. of }\end{array}\right.$

deceased.

agcs

No. of daus. deceased. $\}$

ages

5. Mode of life so far as affecting growth or health.

6. Was early life laborious? why and how?

7. Adult height.

8. General appearance.

9. Bodily strength and energy, if much above or below the average.

so. Keenness or imperfection of sight or other senses.

II. Mental powers and energy, if much above or below the averagc.

82. Character and temperament.

I3. Favorite pursuits and interests.

Artistic aptitudes.

14. Minor ailments to $f$ in youth. which there was spccial liability $($ in middle age.

15. Graver illnesses $\{$ in middle age.

16. Cause and date of death, and age at death.

17. General remarks. 
I. Date of birth.

Birthplace.

2. Occupation.

Residences.

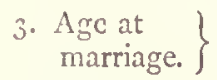

4. ditto of $)$

spousc $\}$

$$
\begin{aligned}
& \text { Total } \\
& \text { No. of }
\end{aligned}\left\{\begin{array}{l}
\text { sons } \\
\text { daus. }
\end{array}\right.
$$

No. of sons deceased.

No. of daus. ? deceased. $\}$ ages

ages

5. Mode of life so far as affecting growth or health.

6. Was early life laborious? why and how?

7. Adult height.

Colour of hair when adult.

Colour of eyes.

8. General appearance.

9. Bodily strength and energy, if much above or below the average.

ro. Keenness or imperfection of sight or other senses.

1I. Mental powers and energy, if much above or bclow the average.

12. Character and temperament.

13. Favoritc pursuits and interests.

Artistic aptitudes.

14. Minor ailments to $f_{\text {in youth. }}$ which there was special liability (in middle age.

15: Graver illnesses $\left\{\begin{array}{l}\text { in youtl. } \\ \text { in middle age. }\end{array}\right.$

16. Cause and date of death, and age at death.

17. General remarks. 
Place in ? pedigree $j$ and )

name
I. Date of birth.

2. Occupation.

$\left.\begin{array}{l}\text { 3. } \begin{array}{l}\text { Age at } \\ \text { marriage. }\end{array}\end{array}\right\}$

4. ditto of 1 spouse $\}$
Birthplace.

Residences.

No. of sons deceased.

ages

No. of daus. deceased.

5. Mode of life so far as affecting growth or health.

6. Was early life laborious? why and how?

7. Adult height.

Colour of hair when adult.

Colour of eyes.

8. General appearance.

9. Bodily strength and energy, if much above or below the average.

10. Keenness or imperfection of sight or other senses.

11. Mental powers and energy, it much above or below the average.

I2. Character and temperament.

I3. Favorite pursuits and interests.

Artistic aptitudes.

14. Minor ailments to $($ in youth. which there was special liability (in middle age.

15. Graver illnesses

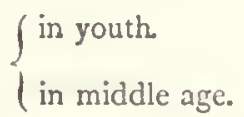

16. Cause and date of death, and age at death.

7. General remarks. 
Place in ? pedigree $\}$

\section{and \\ name}

I. Date of birth.

Birthplace.

2. Occupation.

Residences.

$\left.\begin{array}{l}\text { 3. Age at } \\ \text { marriage. }\end{array}\right\}$

Total $\int^{\text {sons }}$

4. ditto of 1

No. of daus.

No. of sons

deceased.

agcs

No. of daus.

deceased. $\}$

ages

5. Mode of life so far as affecting growth or health.

6. Was carly life laborious? why and how?

7. Adult height.

Colour of hair when adult.

Colour of eyes.

S. General appearance.

9. Bodily strength and energy, if much above or below the average.

10. Keenness or imperfection of sight or other senses.

1I. Nental powers and energy, if much above or below the average.

12. Character and temperament.

I3. liavorite pursuits and interests.

Artistic aptitudes.

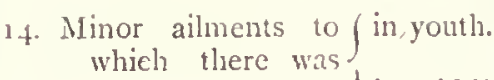
special liability (in middle age.

15. Graver illnesses $\{$ in middle age.

16. Cause and date of death, and age at death.

17. General remarks. 
Birthplace.

×. Date of birth.

Residences.

2. Occupation:

\section{$\left.\begin{array}{l}\text { 3. Age at } \\ \text { marriage. }\end{array}\right\}$} $\left.\begin{array}{c}\text { 4. ditto of } \\ \text { spouse }\end{array}\right\}$

5. Mode of life so far as affecting growth or health.
No. of sons deceased.

No. of daus. deceased. $\}$ ages

ages

6. Was early life laborious? why and how?

7. Adult height.

8. General appearance.

9. Bodily strength and energy, if much above or below the average.

ı. Keenness or imperfection of sight or other senses.

II. Mental powers and energy, if much above or below the average.

12. Character and temperament.

I3. Favorite pursuits and interests.

Artistic aptitudes.

14. Minor ailments to $($ in youth. which there was
special liability

15. Graver illnesses $\left\{\begin{array}{l}\text { in youth. } \\ \text { in middle age. }\end{array}\right.$

16. Cause and date of death, and age at death.

17. General remarks. 
The following pages are to receive entries concerning relatives whose history is so little known that it may seem hardly worth while to devote an entire table to each of them.

The blank pages opposite each of these schedules will serve either for additional facts concerning the persons described in thosc schedules, or to receive notices concerning other relatives.

The four first pages refer to males; the latter four to females. It is convenient on many grounds to keep the entries separate.

The "Place in pedigree" should be described as in the following example :-

$$
\begin{aligned}
& \text { Place in pedigree, Brother of- } \\
& \text { F. F. M. Fane M. Arrowsmith. }
\end{aligned}
$$

(The letters "F. F. M." stand here for "Father's Father's Mother.") 


\section{MALE RELATIONS OF WHOM LITTLE IS KNOWN.}

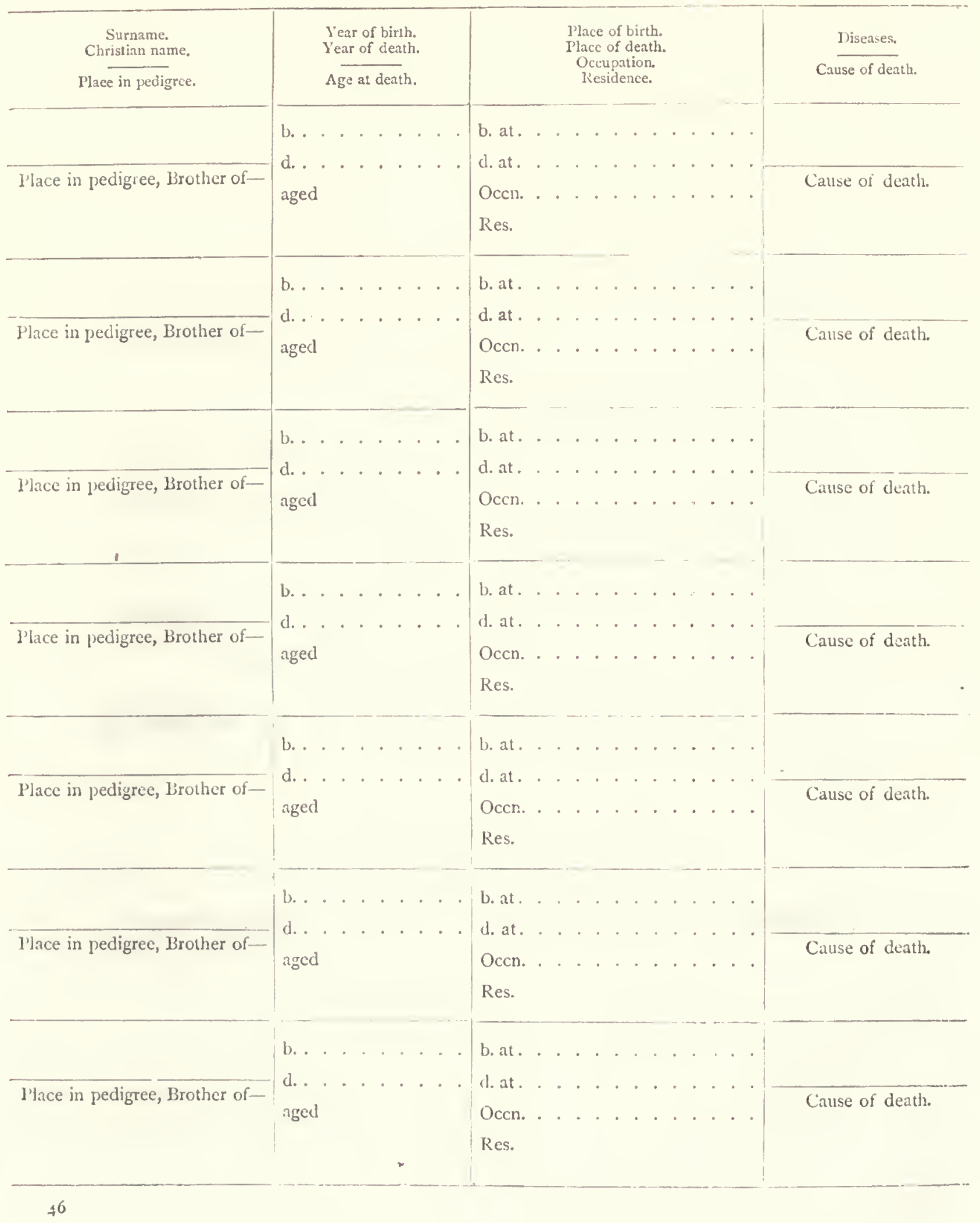





\section{MALE RELATIONS OF WHOM LITTLE IS KNOWN.}

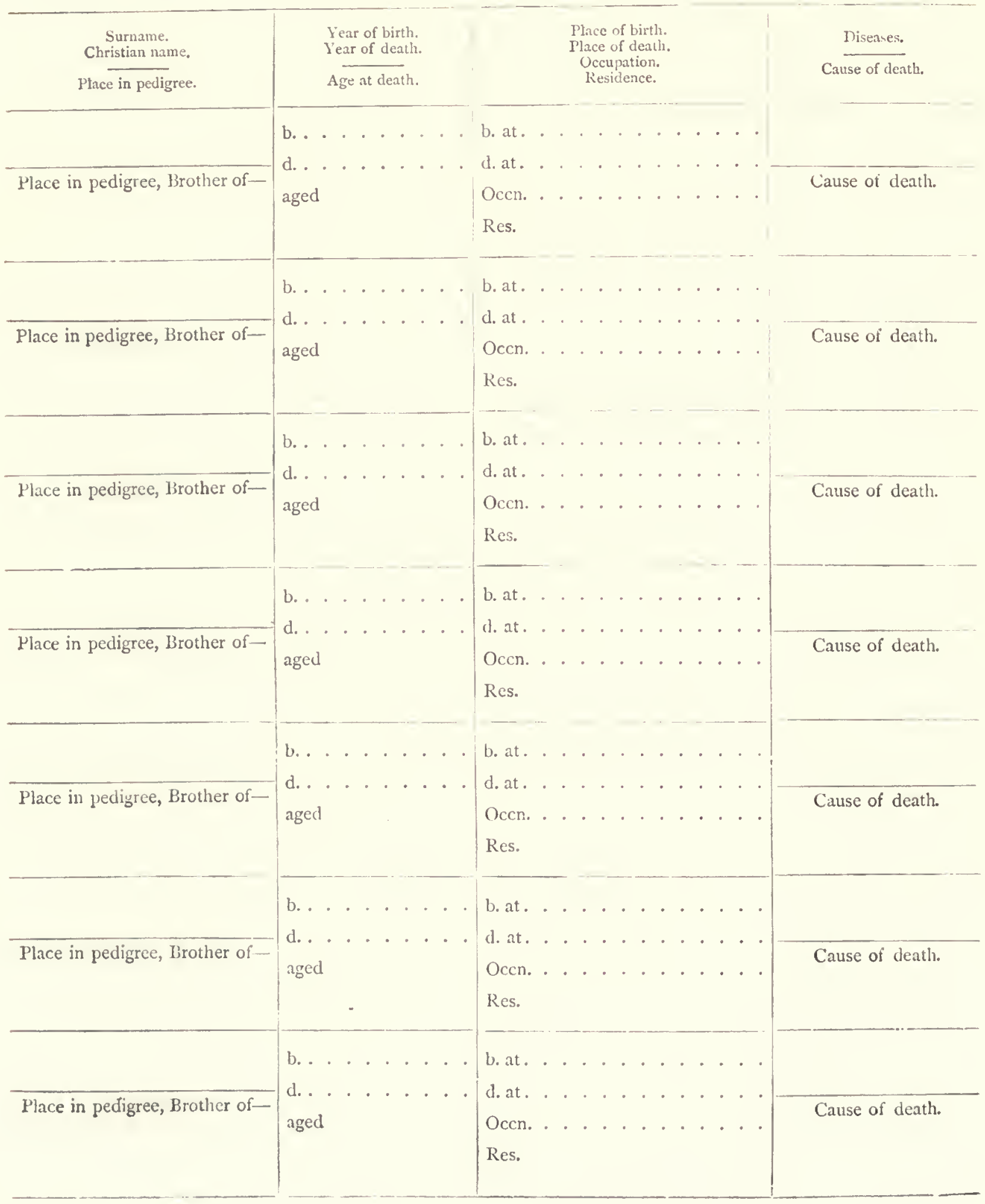


MALE RELATIONS OF WHOM IITTLE IS KNOWN.

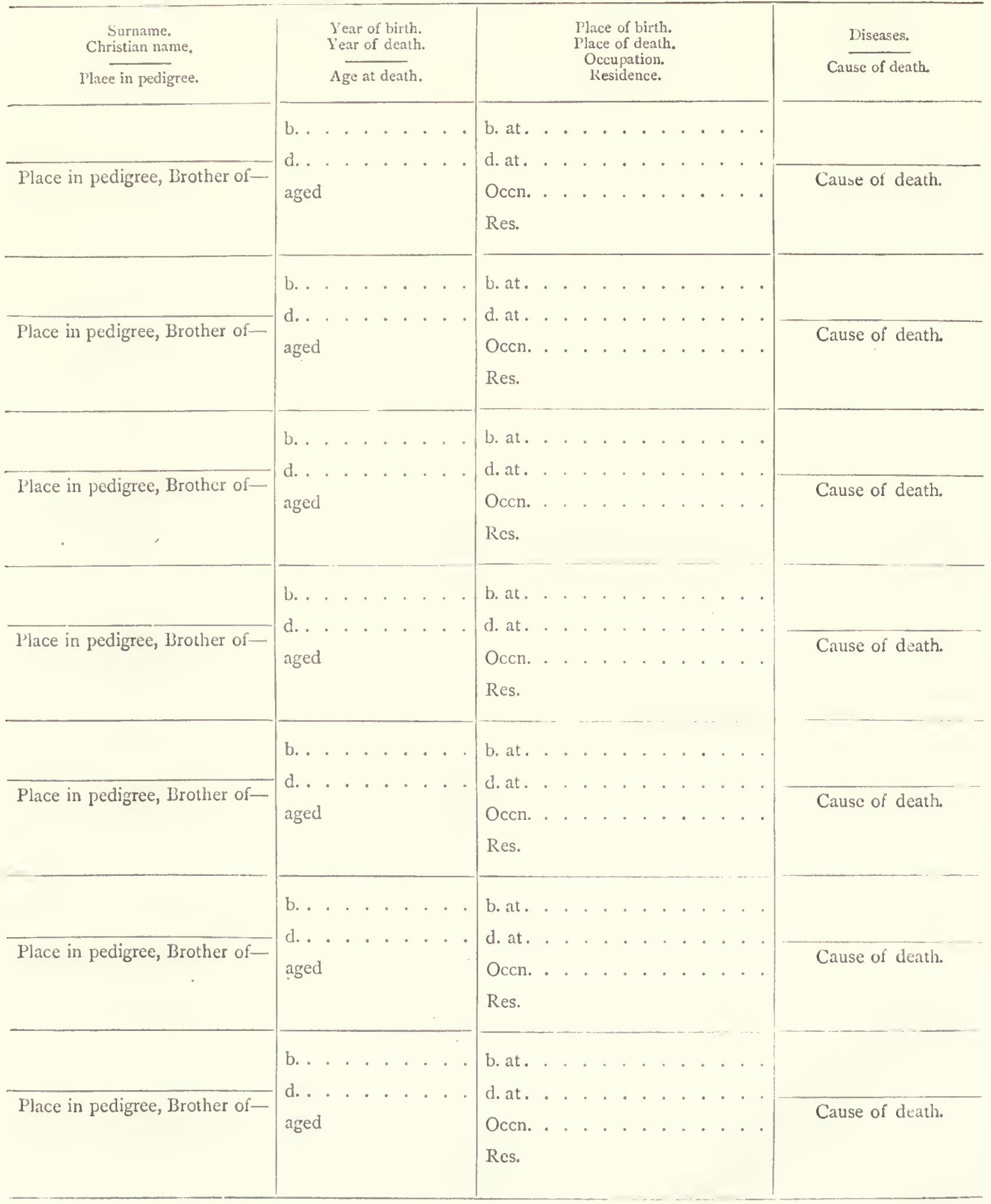




\section{MALE RELATIONS OF WHOM LITTLE IS KNOWN.}

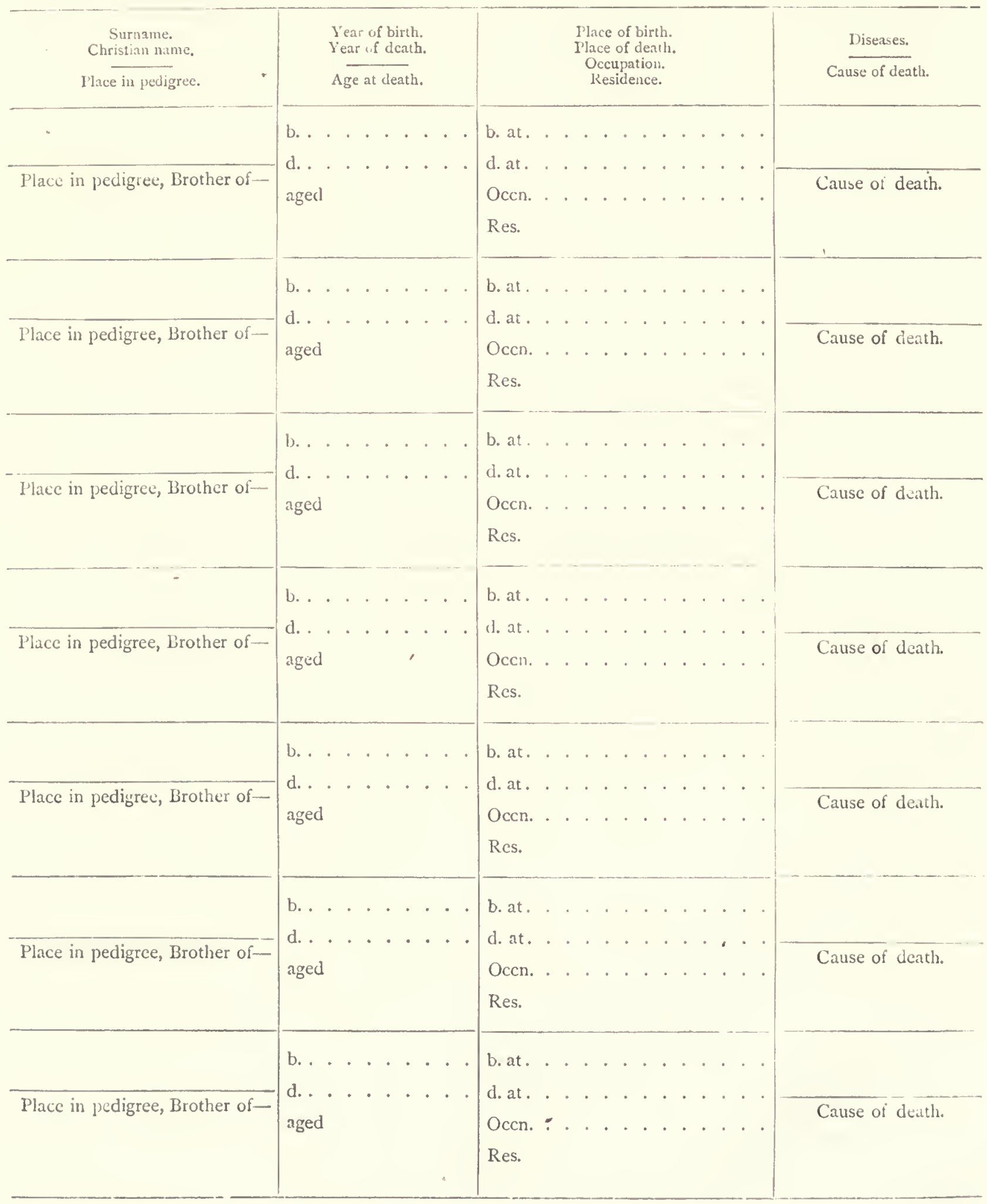


$+$

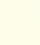

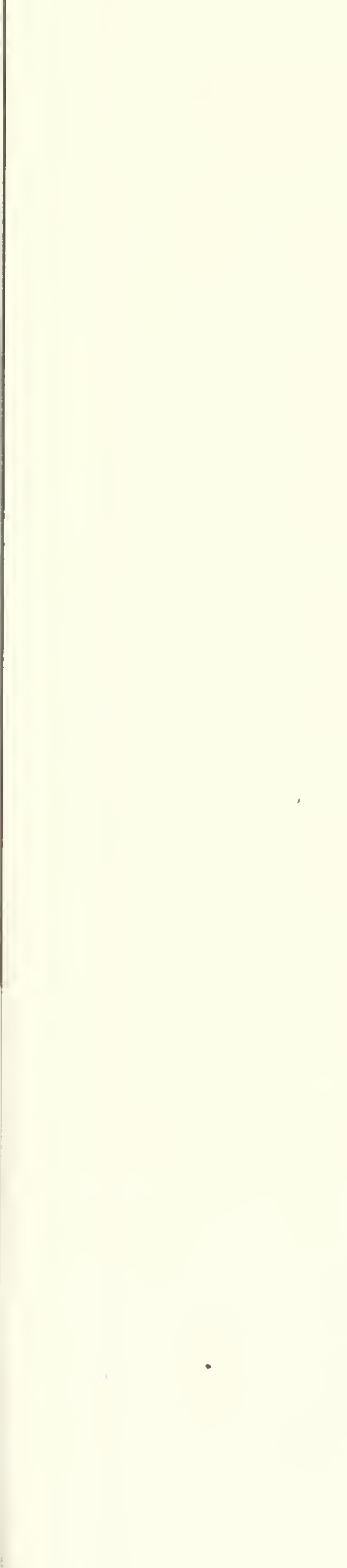

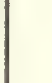

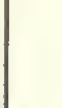

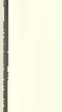
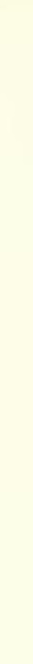


\section{FEMALE RELATIONS OF WHOM LITTLE IS KNOWN.}

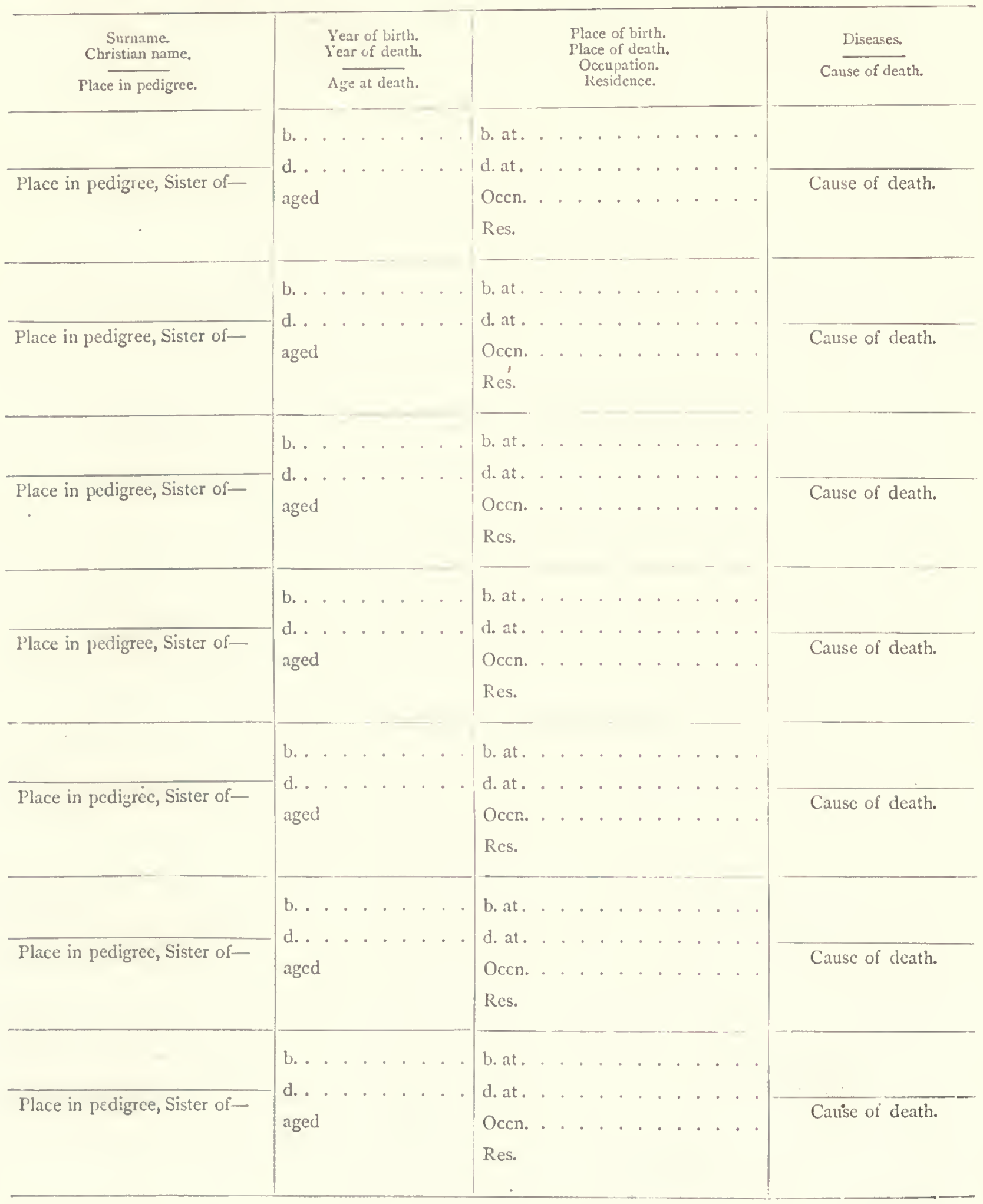





\section{FEMALF RELATIONS OF WHOM LITTLE IS KNOWN.}

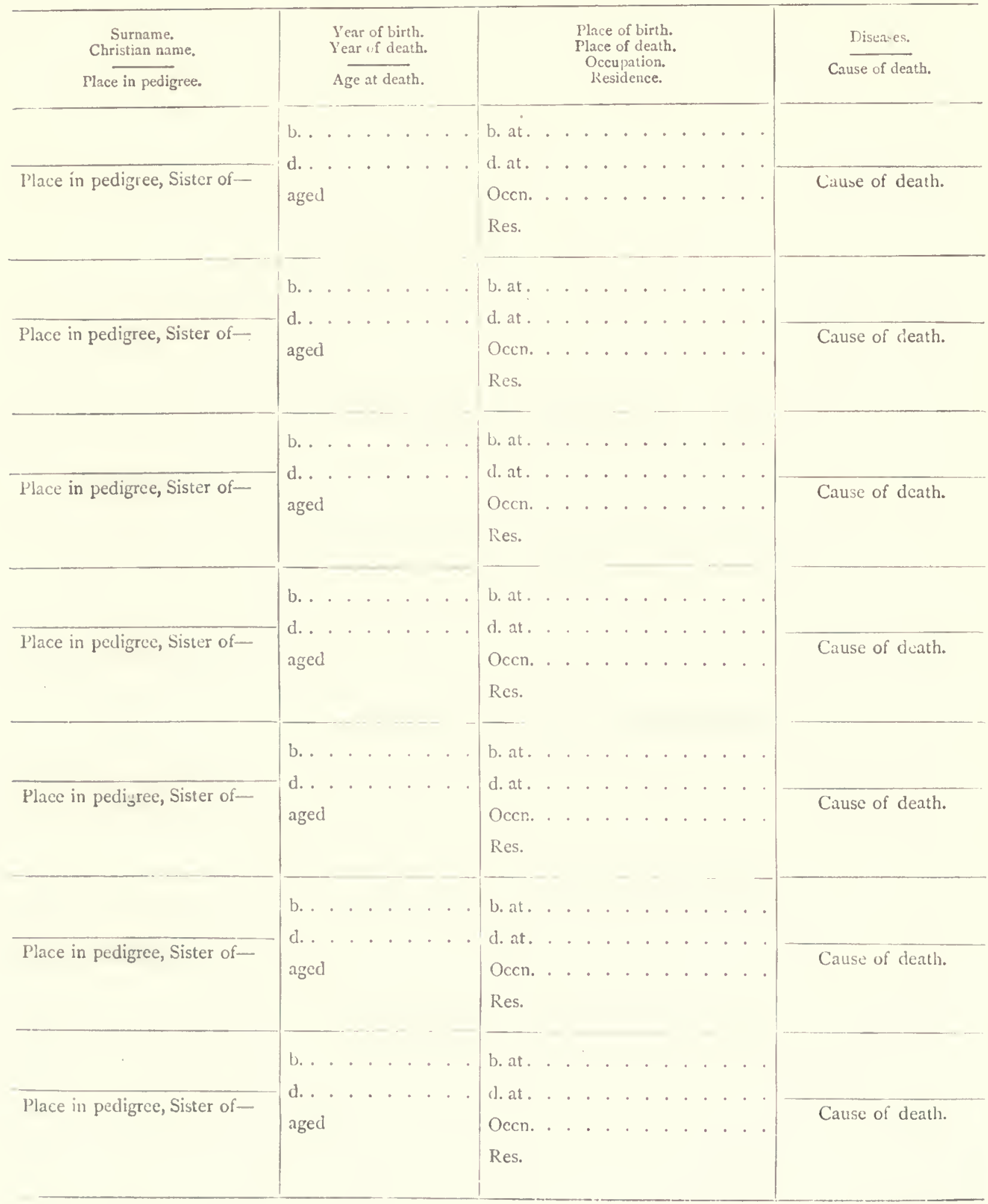




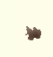




\section{FEMALE RELATIONS OF WHOM LITTLE IS KNOWN.}

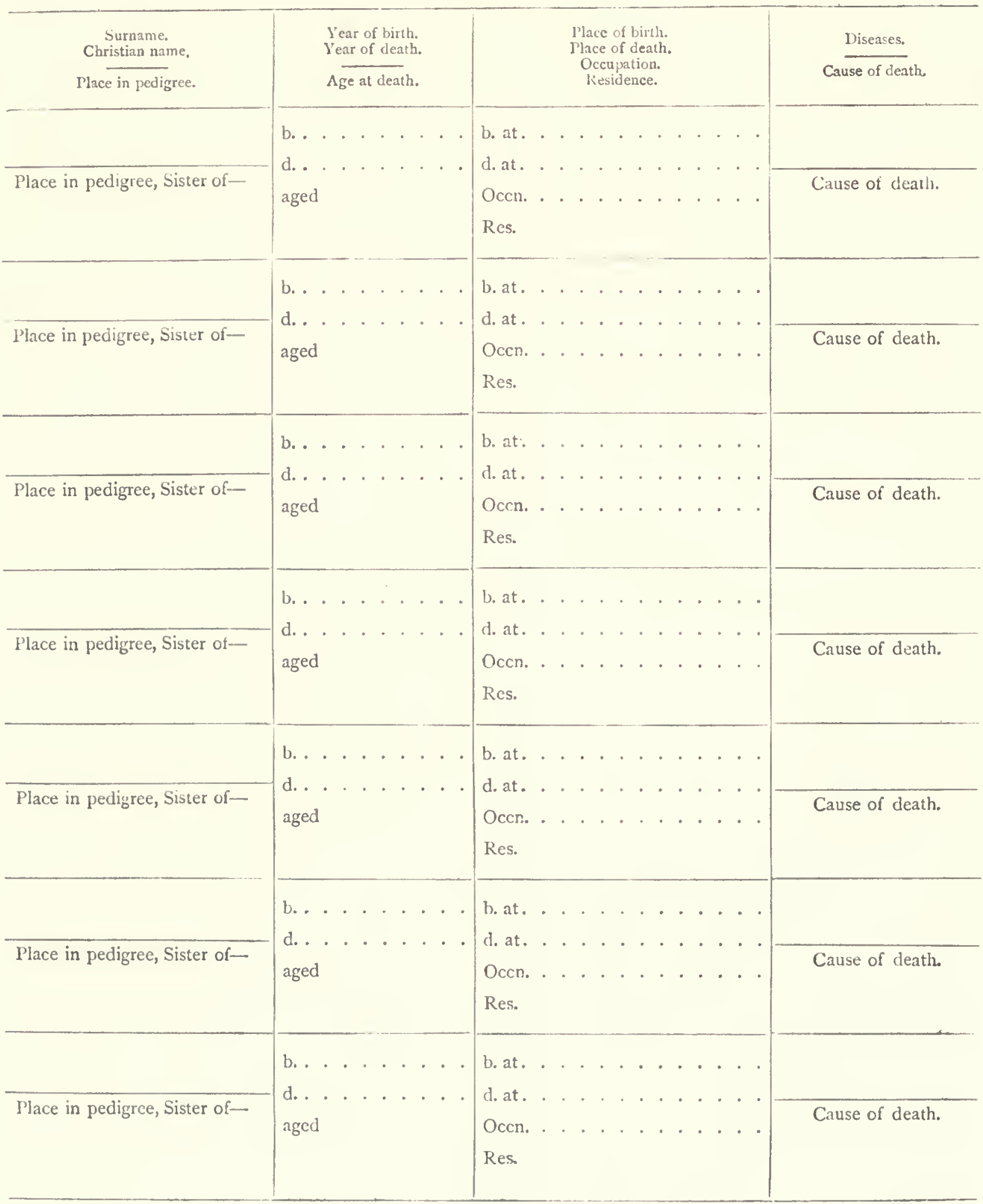





\section{FEMALE RELATIONS OF WHOM IITTLE IS KNOWN.}

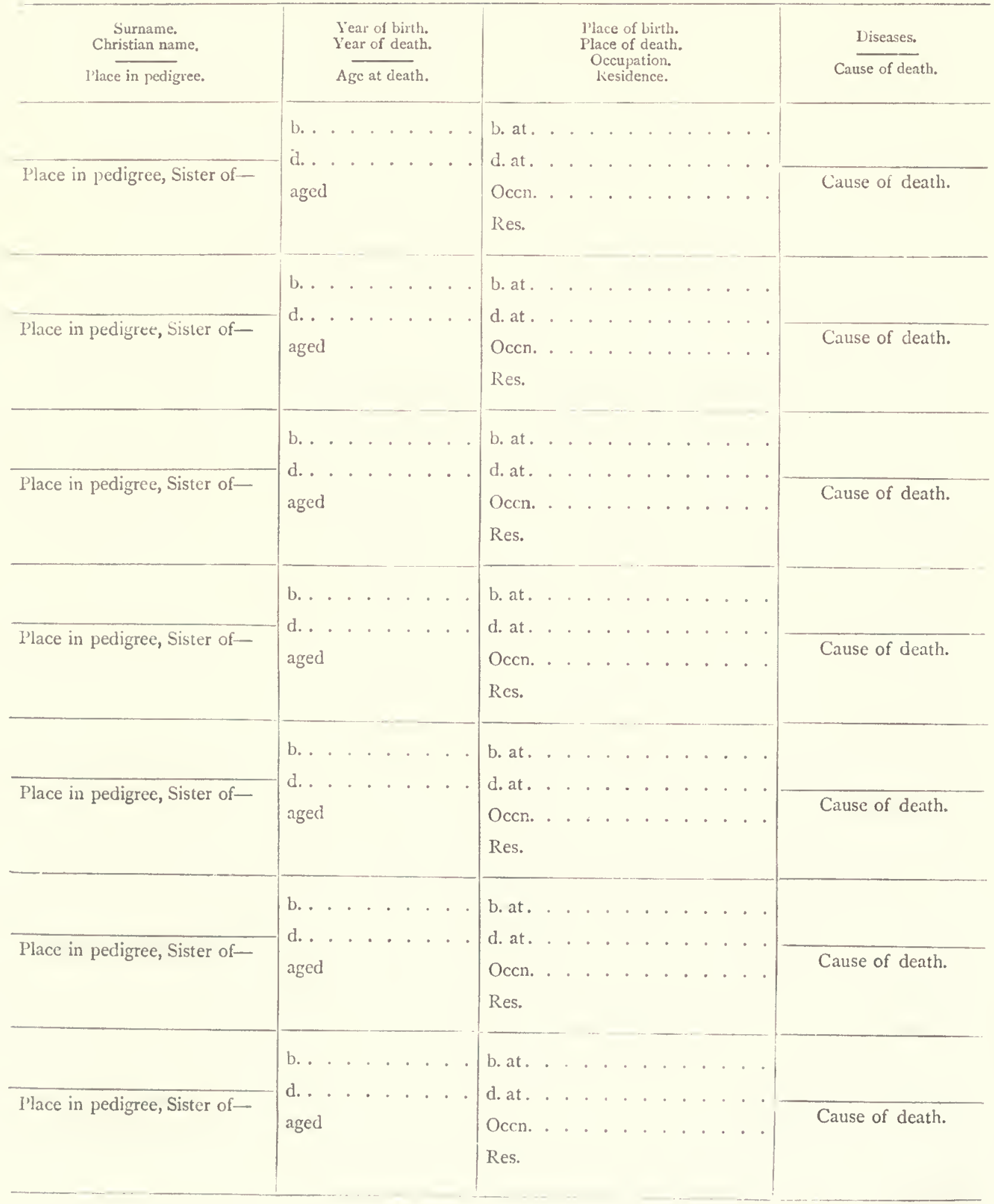


The Summaries in the pages immediately following are to show at a glance the distribution of various qualities in the Family, and must be headed according to the quality in question; thus-

$$
\begin{aligned}
& \text { Summary of the F.Amily Stature and Colour of Hair, } \\
& \text { or, } \\
& \text { Summary of the FAmily Diseases and Longevity. }
\end{aligned}
$$




\section{Page.}

Father 2......... . . . . . $\left\{\begin{array}{l}\text { brothers. } \\ \text { sisters. }\end{array}\right.$

F. F. 4 .

$$
\text { . his }\left\{\begin{array}{l}
\text { brothers. } \\
\text { sisters. }
\end{array}\right.
$$

Ii. M. 5................... her $\left\{\begin{array}{l}\text { brothers } \\ \text { sisters. }\end{array}\right.$

F. F. F. 8................ his $\left\{\begin{array}{l}\text { brothers. } \\ \text { sisters. }\end{array}\right.$

F. F. M. 9................ her $\left\{\begin{array}{l}\text { brothers. } \\ \text { sisters. }\end{array}\right.$

F. M. F. 1о.................. his $\left\{\begin{array}{l}\text { brothers. } \\ \text { sisters. }\end{array}\right.$

F. M. M. II .......... her $\left\{\begin{array}{l}\text { brothers. } \\ \text { sisters. }\end{array}\right.$

Mother 3.............. her $\left\{\begin{array}{l}\text { brothers. } \\ \text { sisters. }\end{array}\right.$

M. F. 6........... his $\left\{\begin{array}{l}\text { brothers. } \\ \text { sisters. }\end{array}\right.$

M. M. 7 .................. her $\left\{\begin{array}{l}\text { brothers. } \\ \text { sisters. }\end{array}\right.$

M. F. F. r2 .................. $\left\{\begin{array}{l}\text { brothers. } \\ \text { sisters. }\end{array}\right.$

M. F. M.13.................... $\left\{\begin{array}{l}\text { brothers. } \\ \text { sisters. }\end{array}\right.$

M. M. F. $\mathrm{I}_{4}$.......... his $\left\{\begin{array}{l}\text { brothers. } \\ \text { sisters. }\end{array}\right.$

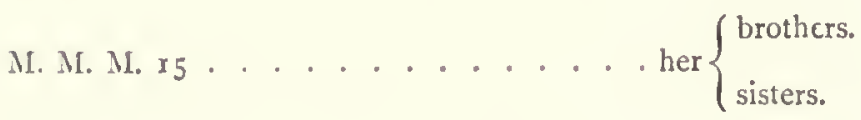




\section{.}




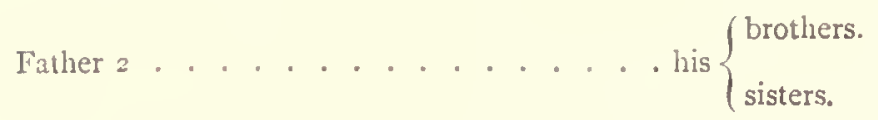

F. F. 4............... his $\left\{\begin{array}{l}\text { brothers. } \\ \text { sisters. }\end{array}\right.$

I. M. 5 . . . . . . . . . . her $\left\{\begin{array}{l}\text { brothers. } \\ \text { sisters. }\end{array}\right.$

F. F. F. 8. . . . . . . his $\left\{\begin{array}{l}\text { bröthers } \\ \text { sisters. }\end{array}\right.$

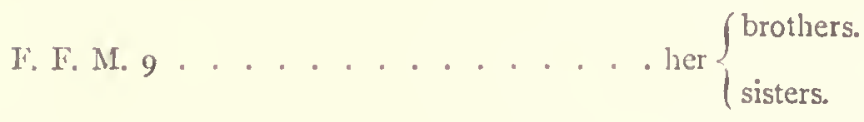

F. M. F. г............... his $\left\{\begin{array}{l}\text { brothers. } \\ \text { sisters. }\end{array}\right.$

F. M. M. $\mathrm{rr} . \ldots . . . . .6$. . . . $\left\{\begin{array}{l}\text { brothers. } \\ \text { sisters. }\end{array}\right.$

Mother 3............... her $\left\{\begin{array}{l}\text { brothers. } \\ \text { sisters. }\end{array}\right.$

M. F. 6............... his $\left\{\begin{array}{l}\text { brothers. } \\ \text { sisters. }\end{array}\right.$

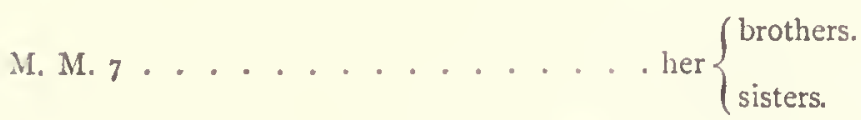

M F. F. 12.................. $\left\{\begin{array}{l}\text { brothers. } \\ \text { sisters. }\end{array}\right.$

M. F. M. $1_{3} \ldots \ldots \ldots$. . . . her $\left\{\begin{array}{l}\text { brothers. } \\ \text { sisters. }\end{array}\right.$

M. M. F. $r_{4} \ldots \ldots$. . . . . $\left\{\begin{array}{l}\text { brothers. } \\ \text { sisters. }\end{array}\right.$

M. M. M. I5 . . . . . . . her $\left\{\begin{array}{l}\text { brothers. } \\ \text { sisters. }\end{array}\right.$ 
APPENDIX I.-Biological History of the Father's Family. 
APPENDIX II.-Biological History of the Mother's Family. 
APPENDIX III.-Inherited Characteristics in the Children. 

RETURN TO the circulation desk of any University of California Library

or to the

NORTHERN REGIONAL LIBRARY FACILITY

Bldg. 400, Richmond Field Station

University of California

Richmond, CA 94804-4698

ALL BOOKS MAY BE RECALLED AFTER 7 DAYS

- 2-month loans may be renewed by calling (510) 642-6753

- T-year loans may be recharged by bringing books to NRLF

- Renewals and recharges may be made 4 days prior to due date.

DUE AS STAMPED BELOW

OCT 282000

SENT ONTLL

MAY 282002

U. C. BERKELEY

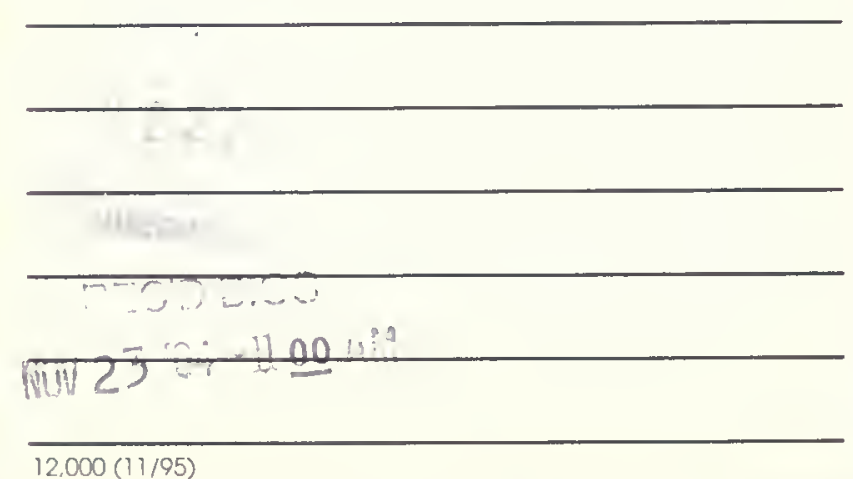

$12,000(11 / 95)$ 


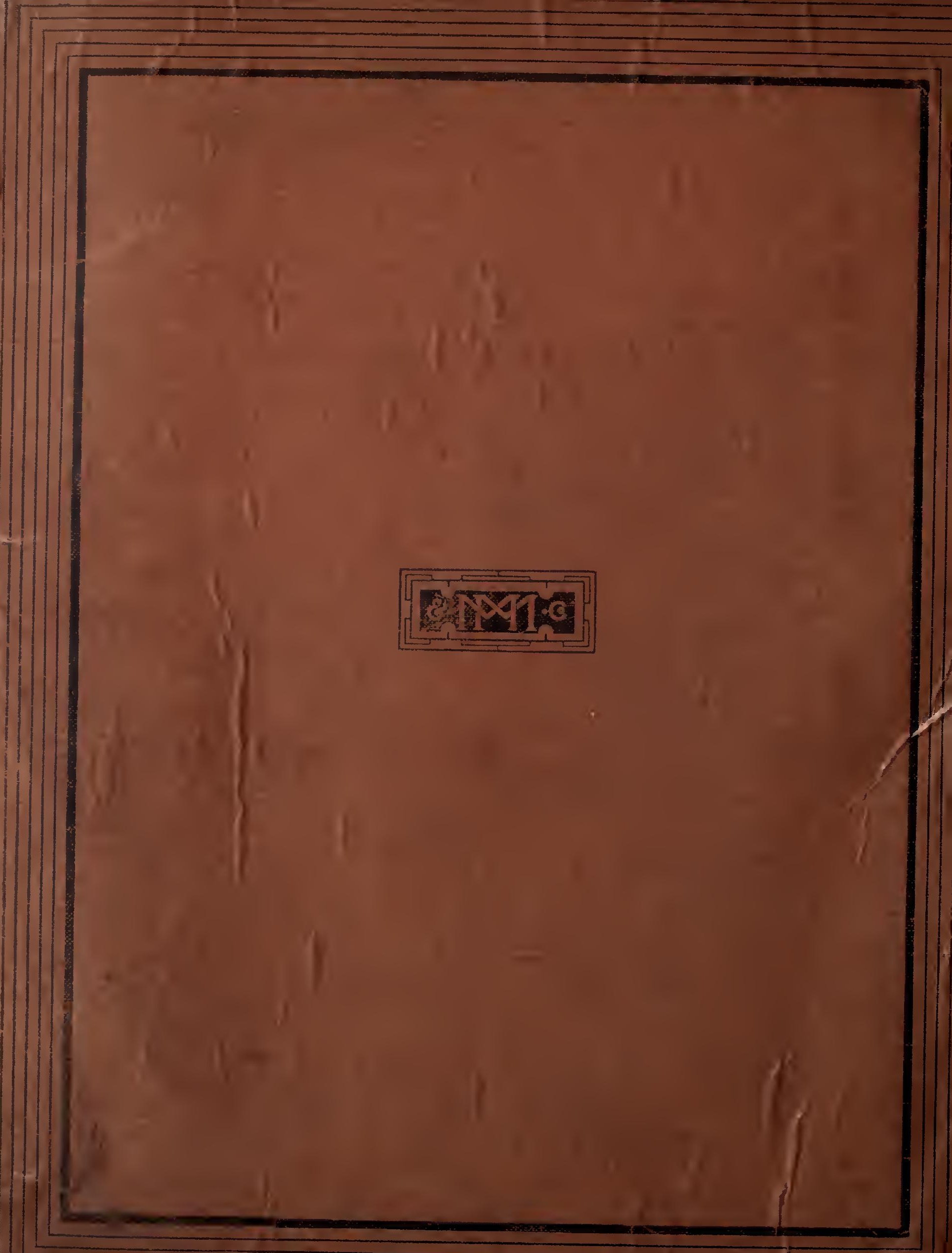

